Chemosphere

Manuscript Draft

Manuscript Number: CHEM58245R2

Title: Occurrence of PPCPs in a Brazilian Water Reservoir and their Removal Efficiency by Ecological Filtration.

Article Type: Research paper

Section/Category: Treatment and Remediation

Keywords: Ecological filtration; drinking water treatment; removal of PPCPS; degradation products.

Corresponding Author: Dr. Caroline Moço Erba Pompei, Ph.D

Corresponding Author's Institution: University of Sao Paulo

First Author: Caroline Moço Erba Pompei, Ph.D

Order of Authors: Caroline Moço Erba Pompei, Ph.D; Luiza C Campos, Ph.D; Bianca F Silva, Ph.D; José C Fogo, Ph.D; Eny M Vieira, Ph.D

Abstract: The presence of PPCPs (Pharmaceuticals and Personal Care Products) in water sources and drinking water has concerned researchers in recent times. This study was carried out to evaluate the occurrence of 6 PPCPs (namely paracetamol, diclofenac, naproxen, ibuprofen, benzophenone-3 and methylparaben) in the Lobo reservoir, their degradation products, and how efficienctly they were removed by 22 ecological filters, considering individual and mixtures of compounds. There were 3 spiking events of PPCPs ( $2 \mu \mathrm{g} \mathrm{L}-1)$ in the ecological filter influents conducted with a lag period of 15 days between spikes. Water sample were collected from the influent and effluent of the filters at 3 , 6 and 24 hours after each spiking event. All target PPCPs were identified in the Lobo reservoir water in the range of $\mu \mathrm{g} \mathrm{L}-1$. The personal care products were detected with $100 \%$ frequency in the samples, and in higher concentrations compared to the pharmaceuticals. Degradation products of diclofenac and benzophenone-3 were identified in the water samples. Results of this investigation show that an ecological filter was an effective process (70 - $99 \%$ ) to remove $2 \mu \mathrm{g} \mathrm{L-1}$ of the selected PPCPs, and demonstrated that the filters were resilient to individual compounds and to their mixtures. 

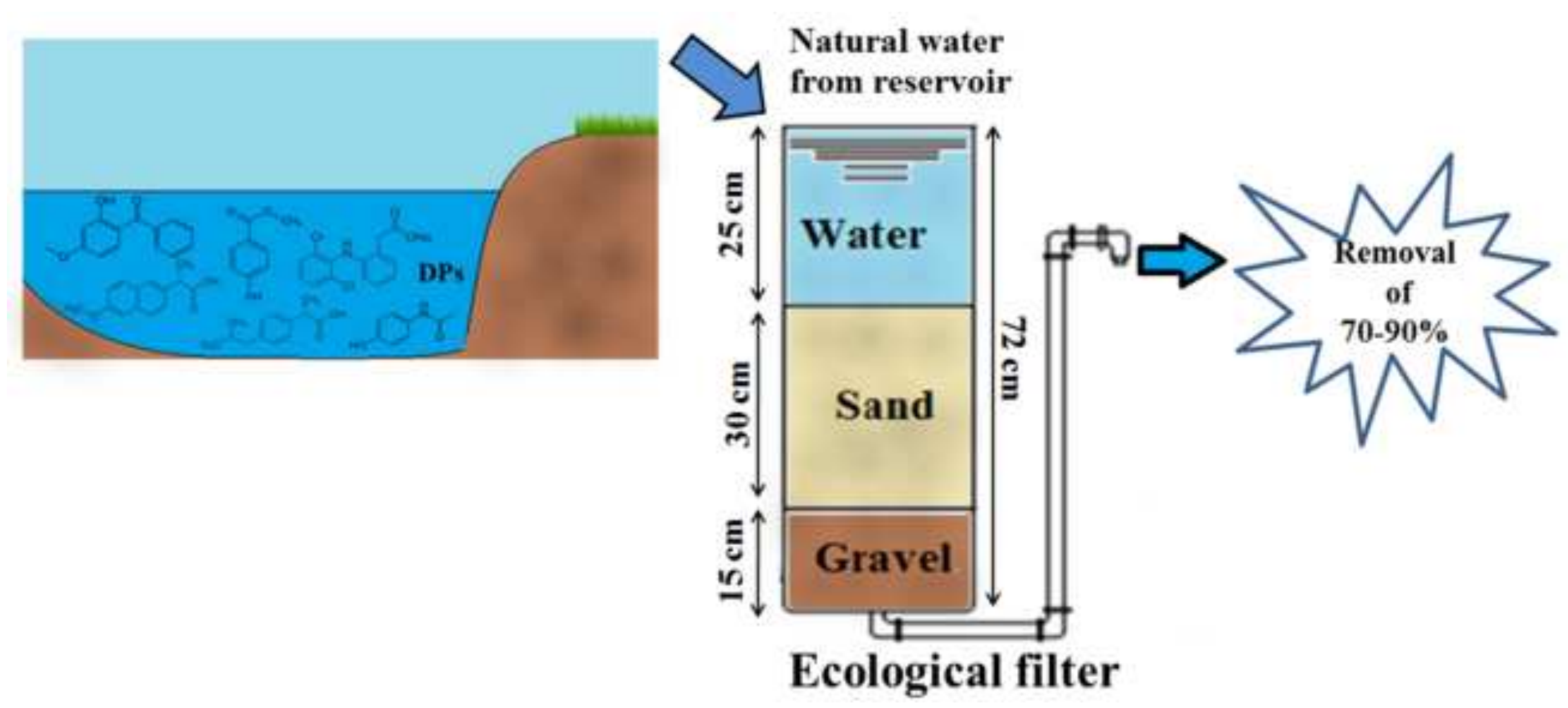

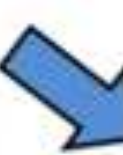

Natural water

from reservoir

Ecological fiter 
Chemosphere

14 November 2018

Dear Editors,

I am writing to put forward the manuscript entitled "Occurrence of PPCPs in a Brazilian Water Reservoir and their Removal by Ecological Filtration.", authored by Caroline Moço Erba Pompei; Luiza C. Campos; Bianca Ferreira da Silva; José Carlos Fogo; Eny Maria Vieira.

The authors strongly believe that this work relates to the aims and scope of the Chemosphere. The paper describes a unique experimental work carried out to investigate the occurrence of six selected PPCPs in a Brazilian water reservoir and their removal by an ecological filtration system consisted of 22 filters receiving the reservoir water. The research investigated the efficiency of the filters to remove individual target PPCPs and their mixture, being each filter and water samples in triplicates.

This paper is of interest to researchers and practitioners working with biological filtration, low cost techniques to drinking water and with interest in understanding the contamination of freshwater by PPCPs and their removal by ecological filtration.

The authors state that the paper is not being submitted elsewhere and their contents have not been previously published. The authors also state that there are no competing interests and the authors' contributions to the manuscript are: Caroline Moço Erba Pompei carried out the research and led the paper preparation; Luiza C. Campos supported manuscript preparation and submission, Bianca Ferreira da Silva supervised the LC/MSMS analysis and reviewed the paper;; José Carlos Fogo supported the statistical analyzes and reviewed the paper; and Eny Maria Vieira supervised the research and reviewed the paper. In addition to myself, we would like to include Dr Luiza C. Campos as co-corresponding author, given her significant contribution during the preparation and corrections of the manuscript.

Yours faithfully,

Candime Mow Eiba Pompa

Dr. Caroline Moço Erba Pompei 


\section{Occurrence of PPCPs in a Brazilian Water Reservoir and their Removal Efficiency by Ecological Filtration.}

Caroline Moço Erba Pompei ${ }^{1 *}$; Luiza Cintra Campos ${ }^{2 * *}$; Bianca Ferreira da Silva ${ }^{3}$;osé Carlos $\mathrm{Fogo}^{4}$; Eny Maria Vieira ${ }^{5}$.

1. Water Resources and Applied Ecology Center, São Carlos School of Engineering, University of São Paulo, São Carlos, SP, Brazil. E-mail: caroline_erba@yahoo.com.br

2. Department of Civil, Environmental and Geomatic Engineering, University College London, Gower Street, London WC1E 6BT, United Kingdom. E-mail: 1.campos@ucl.ac.uk

3. Institute of Chemistry - State University “Julio de Mesquita Filho”-UNESPAraraquara, SP, Brazil. E-mail: biribisfs@gmail.com

4. Department of Statistics, Federal University of São Carlos, SP, Brazil. E-mail: fogo@ufscar.br

5. Department of Chemistry and Molecular Physics, São Carlos Institute of Chemistry, University of São Paulo, São Carlos, SP, Brazil. E-mail: eny@iqsc.usp.br

*Corresponding author

**Corresponding author

E-mails: *caroline_erba@yahoo.com.br;**1.campos@ucl.ac.uk

Postal addresses: *Avenida Trabalhador São Carlense, 400, Caixa Postal 292, São Carlos, SP, CEP 13560-970. **Department of Civil, Environmental and Geomatic Engineering, University College London, Chadwick Building, Room GM11, Gower Street, London WC1E 6BT, United Kingdom 


\section{Occurrence of PPCPs in a Brazilian Water Reservoir and their Removal Efficiency by Ecological Filtration.}

Caroline Moço Erba Pompei ${ }^{1 *}$; Luiza Cintra Campos ${ }^{2 * *}$; Bianca Ferreira da Silva ${ }^{3}$;osé Carlos $\mathrm{Fogo}^{4}$; Eny Maria Vieira ${ }^{5}$.

1. Water Resources and Applied Ecology Center, São Carlos School of Engineering, University of São Paulo, São Carlos, SP, Brazil. E-mail: caroline_erba@yahoo.com.br

2. Department of Civil, Environmental and Geomatic Engineering, University College London, Gower Street, London WC1E 6BT, United Kingdom. E-mail: 1.campos@ucl.ac.uk

3. Institute of Chemistry - State University “Julio de Mesquita Filho"-UNESPAraraquara, SP, Brazil. E-mail: biribisfs@gmail.com

4. Department of Statistics, Federal University of São Carlos, SP, Brazil. E-mail: fogo@ufscar.br

5. Department of Chemistry and Molecular Physics, São Carlos Institute of Chemistry, University of São Paulo, São Carlos, SP, Brazil. E-mail: eny@iqsc.usp.br

*Corresponding author

**Corresponding author

E-mails: *caroline_erba@yahoo.com.br; **1.campos@ucl.ac.uk

Postal addresses: *Avenida Trabalhador São Carlense, 400, Caixa Postal 292, São Carlos, SP, CEP 13560-970. **Department of Civil, Environmental and Geomatic Engineering, University College London, Chadwick Building, Room GM11, Gower Street, London WC1E 6BT, United Kingdom 


\section{Highlights}

- Six PPCPs were found in the reservoir water, and personal care products had $100 \%$ of frequency;

- Two DPs were found in the reservoir water and ecological filter effluents;

- Performance of the ecological filters was not affected by PPCP contamination;

- $2 \mu \mathrm{g} \mathrm{L} \mathrm{L}^{-1}$ of PPCPs were effectively removed by all ecological filters (70-99\%);

- Results show that filters are resilient to individual PPCP and their mixture. 
12 March 2019.

\section{Dear Editors,}

Thank you very much for giving us the chance of correcting and improving our manuscript further.

We inform that the manuscript and all associated files have been reviewed by a native English speaker.

Considering our initial request in the cover letter submitted with our first manuscript submission, we would like to inform that we have added Dr Luiza C. Campos as a cocorresponding author in this corrected version. Dr Campos will support dealing with queries after the paper publication.

Yours faithfully,

$$
\text { Candine Mow Eiba Pompa }
$$

Dr. Caroline Moço Erba Pompei 


\section{Occurrence of PPCPs in a Brazilian Water Reservoir and their Removal Efficiency} by Ecological Filtration.

Caroline Moço Erba Pompei ${ }^{1 *}$; Luiza Cintra Campos ${ }^{2 * *}$; Bianca Ferreira da Silva ${ }^{3}$; José Carlos Fogo ${ }^{4}$; Eny Maria Vieira ${ }^{5}$.

\section{Water Resources and Applied Ecology Center, São Carlos School of} Engineering, University of São Paulo, São Carlos, SP, Brazil. E-mail: caroline_erba@yahoo.com.br

2. Department of Civil, Environmental and Geomatic Engineering, University College London, Gower Street, London WC1E 6BT, United Kingdom. E-mail: 1.campos@ucl.ac.uk

3. Institute of Chemistry - State University “Julio de Mesquita Filho”-UNESPAraraquara, SP, Brazil. E-mail: biribisfs@gmail.com

4. Department of Statistics, Federal University of São Carlos, SP, Brazil. E-mail: fogo@ufscar.br

5. Department of Chemistry and Molecular Physics, São Carlos Institute of Chemistry, University of São Paulo, São Carlos, SP, Brazil. E-mail: eny@iqsc.usp.br

\section{*Corresponding author}

**Corresponding author

E-mails: *caroline_erba@yahoo.com.br; **1.campos@ucl.ac.uk

Postal addresses: *Avenida Trabalhador São Carlense, 400, Caixa Postal 292, São Carlos, SP, CEP 13560-970. **Department of Civil, Environmental and Geomatic Engineering, University College London, Chadwick Building, Room GM11, Gower Street, London WC1E 6BT, United Kingdom 


\section{Abstract}

The presence of PPCPs (Pharmaceuticals and Personal Care Products) in water sources and drinking water has concerned researchers in recent times. This study was carried out to evaluate the occurrence of 6 PPCPs (namely paracetamol, diclofenac, naproxen, ibuprofen, benzophenone-3 and methylparaben) in the Lobo reservoir, their degradation products, and howtheir efficienctly they werey removedals by 22 ecological filters, considering individual and a-mixtures of compounds. There were eonducted 3 spiking events of PPCPs $\left(2 \mu \mathrm{g} \mathrm{L}{ }^{-1}\right)$ in the ecological filter influents conducted with a lag period of 15 days between spikes. Water samplings-sample were collected from the influent and effluent of the filters at 3,6 and 24 hours after each spiking events. All target PPCPs were identified in the Lobo reservoir water in the range of $\mu \mathrm{g} \mathrm{L}^{-1}$. The personal care products were detected with $100 \%$ of -frequency in the samples, and in higher concentrations compared to the pharmaceuticals. Degradation products of diclofenac and benzophenone-3 were identified in the water samples. Results of this investigation show that an ecological filter was an effective process $(70-99 \%)$ to remove $2 \mu \mathrm{g} \mathrm{L}^{-1}$ of the selected PPCPs, and demonstrated that the filters were resilient to individual compounds and to their mixtures.

Keywords: Ecological filtration; drinking water treatment; removal of PPCPs; degradation products. 


\section{Introduction}

Pharmaceuticals and Personal Care Products (PPCPs) are of scientific and public concern as newly recognized classes of environmental pollutants; described as emerging water contaminants with potential psychoactive properties and unknown effects to the aquatic environment (Evgenidou et al., 2015). The term "PPCPs" refers to any chemical product with healthcare or medical purposes for humans and/or animals (Schumock et al. 2014).

The most consumed non-steroidal anti-inflammatory drugs frequently found in aquatic environments are aspirin, acetaminophen, ibuprofen, naproxen and diclofenac (Fent et al., 2006). These PPCPs and others have been detected worldwide in surface water, groundwater, sewage and even drinking water in the order of $n g-\mu g \mathrm{~L}^{-1}$ (Heberer, 2002; Petrović et al., 2003; Fent et al., 2006; Ellis, 2006; Sui et al., 2015). AdditionallyAlso, degradation products (DPs) of these PPCPs have been found in water bodies and water samples after treatment, as a result of a multiplicity of biotic and abiotic processes (e.g. hydrolysis, photolysis, oxidation, and microbiological metabolism) acting on the original compounds or their metabolites (Mompelat et al., 2009; Dévier et al., 2011; Andrés-Costa et al., 2014; Van Doorslaer et al., 2014; Postigo and Richardson, 2014).

PPCP removal has been observed in wastewater treatment plants (WWTPs) (e.g. Ternes et al., 1998; Thomas and Foster, 2004, Camacho-Munoz et al., 2012). However, in general $_{2}$ most of WWTPs are not designed to treat this type of substance, and consequently a significantlysignificant portion of these compounds are not degraded/removed during treatment. Therefore, the pure compound and/or their metabolites may enter the aquatic environment via sewage effuents (Daughton and Ternes, 1999; Heberer, 2002; Petrović et al., 2003; Jones et al., 2005; Fent et al., 2006; 
Matamoros et al., 2009)._-FurthermoreAlse, conventional drinking water treatment processes have been reported as ineffective for the removal of most pharmaceuticals, with efficiency ranging from $<5$ to $40 \%$ (Vieno et al., 2007; Pojana et al., 2011). . Recently, numerous many investigations have been carried out using advanced oxidation processes (AOPs) such as ozonation, UV oxidation, fenton and fenton-like processes, and photocatalytic degradation to remove PPCPs from water and wastewater (Tayo et al., 2018; Goel and Das, 2018; Xu et al., 2017). However, the relatively high cost of these processes currently stand as the major barrier for their large-scale implementation (Xu et al., 2017), especially in developing countries such as Brazil. ConverselyOn the other hand, there are -is evidence of PPCP removal by sandfiltration, in which biodegradation has been suggested as one of the removal mechanisms (Westerhoff, 2003; Fujii and Kikuchi, 2005; Hallé, 2010; Onesios et al., 2009; Camacho-Munoz et al. 2012; Chen et al., 2015; Chen et al., 2016). For example, Qiao et al. (2011) investigating investigated the occurrence of 15 PPCPs in two full-scale conventional treatment plants,-; they found that the type and concentration of PPCP decreased gradually along the treatment train, especially after sand filtration. Beretelkamp et al. (2014), simulating simulated the removal of 14 organic compounds by river bank filtration at a laboratory scale,-; they obtained a statistically significant relationship between the biological degradation rates and the compound functional groups. In addition, removal of PPCPs has been observed in slow sand filtration (SSF) and granular activated carbon (GAC) sandwich SSF (Erba et al., 2014; Escolà Casas and Bester, 2015; Pompei et al., 2017; Li et al., 2018). Therefore, biosandfiltration seems an attractive option due to its demonstrated potential of removing PPCPs from water and its low operational cost for not requiring chemical coagulation. Slow sand filtration has been recently referred to as ecological filtration due to the presence of a biofilm that
Formatted: No underline, Font color: Auto, English (United Kingdom)

Formatted: English (United Kingdom)

Formatted: No underline, Font color: Auto, English (United Kingdom) 
forms on top of the sand filter and is believed to be essential to water purification (Nakamoto, 2008).

The aim of this work was to evaluate the occurrence of selected PPCPs and DPs in a Brazilian water reservoir ${ }_{2 \bar{i}}$ and their removal by ecological filters installed under natural environmental conditions, receiving water from the Lobo reservoir in Itirapina, São Paulo state. To the best of the authors' knowekedgeknowledge, this is the first study investigating the removal of individual target compounds, their mixture, and their degradation products by ecological filtration at a pilot scale.

\section{Material and methods}

\subsection{Chemicals and Reagents}

Acetonitrile $\left(\mathrm{CH}_{3} \mathrm{CN}\right)$ and methanol $\left(\mathrm{CH}_{3} \mathrm{OH}\right)$ were of HPLC grade from J.T.

Baker (Xalostoc, México); - „ formic Formic acid; _ 4-Acetaminophen (ACT), Diclofenac sodium salt (DCF), Naproxen (NAP), Ibuprofen (IBU), Metyl 4hydroxybenzoate (MEP) and 2-Hydroxy-4-methoxybenzophenone (BP-3) (all $99 \%$ purity or more) were purchased from Sigma-Aldrich. The deuterated compounds were used as internal standards, namely paracetamol- $d 4$, diclofenac- $d 4$, naproxen- $d 3$, ibuprofen- $d 3$; all obtained from $\mathrm{CDN}$ Isotopes (Quebec, Canada). Additional information about each compound is shown in Table S1. Stock solutions were prepared in methanol for each compound and stored in a refrigerator at $4{ }^{\circ} \mathrm{C}$. For all reagent solutions, water was previously distilled and further deionized using a Milli-Q system Millipore (Millipore, Bedford, MA, USA).

\subsection{Filter construction}

Formatted: English (United Kingdom)

Formatted: No underline, Font color: Auto, English (United Kingdom)

Formatted: No underline, Font color: Auto, English (United Kingdom)

Formatted: No underline, Font color: Auto, English (United Kingdom)

Formatted: English (United Kingdom)

Formatted: No underline, Font color: Auto, English (United Kingdom)

Formatted: English (United Kingdom) Formatted: No underline, Font color: Auto, English (United Kingdom)

Formatted: English (United Kingdom)

Formatted: Font: No underline, Font color: Auto, English (United Kingdom)

Formatted: Font: No underline, Font color: Auto, English (United Kingdom)

Formatted: Font: No underline, Font color: Auto, English (United Kingdom)

Formatted: English (United Kingdom)

Formatted: No underline, Font color: Auto, English (United Kingdom)

Formatted: English (United Kingdom) 
Twenty-two ecological filters (Nakamoto, 2008) were constructed with PVC

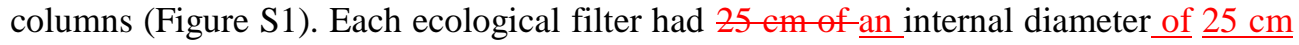
and height of $72 \mathrm{~cm}$. The support layer in each filter was formed by a $15 \mathrm{~cm}$ gravel layer, with 3 sub-layers of $12.50 \mathrm{~mm}$ to $1.41 \mathrm{~mm}$. The sand layer had $30 \mathrm{~cm}$ height with grain sizes varying from 1.00 to $0.08 \mathrm{~mm}$. The sand uniformity eeefieientcoefficient was between 2 and 3, and the effective grain size was $0.25 \mathrm{~mm}$ (Bellamy et al., 1985; Di Bernardo, 1993). The water layer on the top of the sand bed varied from 25 to $27 \mathrm{~cm}$. The influent water to the 22 ecological filters was pumped from the Lobo reservoir $\left(22^{\circ} 10^{\prime} 18.09^{\prime S} 47^{\circ} 54^{\prime} 5.00^{\prime \prime} \mathrm{W}\right)$, located at Itirapina city, São Paulo, Brazil, to a constant level tank before being supplied continuously to the filters.

\subsection{Water Sampling}

The operation of filters was continuous and the average water filtration flow rate was $3 \mathrm{~m}^{3} / \mathrm{d} \cdot \mathrm{m}^{2}$. There was triplicate of six 6 filters with receiving each individually receiving a each-PPCP compound (18 filters), triplicate of ene -1 filter receiving a mixture of the 6 PPCP compounds ( 3 filters), and one -1 control filter receiving only water from the Lobo reservoir (Table S2).

After maturation of the filters, three spiking events of the target PPCPs were conducted with a lag period of 15 days between spikes. The spikes were created made to certify that a known concentration would enter the ecological filters, as the main concentration of PPCPs on the reservoir water may vary and may not be detected every day. The spike solution (1L) was added to the raw water inlet via a dosing pump. Samples of the reservoir water were collected at the same time as the filter effluent water $(3,6$, and 24 hours after spikes) to determine the background concentration of the target PPCPs. The point of water sample collection in the reservoir was always the
Formatted: No underline, Font color: Auto, English (United Kingdom)

Formatted: No underline, Font color: Auto, English (United Kingdom)

Formatted: English (United Kingdom)

Formatted: No underline, Font color: Auto, English (United Kingdom)

Formatted: English (United Kingdom)

Formatted: No underline, Font color: Auto, English (United Kingdom)

Formatted: No underline, Font color: Auto, English (United Kingdom)

Formatted: No underline, Font color: Auto, English (United Kingdom)

Formatted: No underline, Font color: Auto, English (United Kingdom)

Formatted: No underline, Font color: Auto, English (United Kingdom)

Formatted: No underline, Font color: Auto, English (United Kingdom)

Formatted: No underline, Font color: Auto, English (United Kingdom)

Formatted: English (United Kingdom)

Formatted: No underline, Font color: Auto, English (United Kingdom) 
same, which is the place where is locatedat the location of the hydraulic pump used to supply the 22 filters $\left(22^{\circ} 10^{\prime} 18.09^{\prime \prime S} 47^{\circ} 54^{\prime} 5.00^{\prime \prime} \mathrm{W}\right)$.

For PPCP detection, water samples $(500 \mathrm{~mL}$-each) were collected in each contaminated filter after each every contamination event (total per filter $=3$ samples (triplicate) $\times 3$ spike events $=9$ samples; total $=189$ samples $),$ while in the control filter only 9 samples were collected in total. To evaluate the removal efficiency of each filter, the total initial concentration of each target PPCP compound was considered to beas the

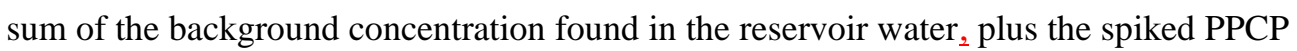
concentration of $2 \mu \mathrm{g} \mathrm{L}^{-1}$. For physico-chemical and bacteriological analyses, samples of $500 \mathrm{~mL}$ each-were collected weekly from the influent and effluent of each filter during the first month of operation; and-they were also collected from $9^{\text {th }}$ October in 2013, when the filters were considered matured, water samples were collected 3 times per week (samples in each filter $=30 ;$ total samples $=660$ samples $).$

\subsubsection{Water quality parameters}

Parameters concerning the treated water quality by the ecological filters were measured from September to December 2013. Turbidity and apparent colour were determined by a HACH DR 2000 espectrofotometer, selecting $\mathrm{UV}_{455 \mathrm{~nm}}$ for colour and $\mathrm{UV}_{750 \mathrm{~nm}}$ for turbidity. The true colour was measured after filtering the water samples through a $0.45 \mu \mathrm{m}$ membrane (Millipore, cellulose ester, $90 \mathrm{~mm}$ diameter), and determined using the espectrofotometer at $\mathrm{UV}_{455 \mathrm{~nm}}$. The $\mathrm{pH}$ was determined by $\mathrm{pHmeter}$ B374 - Micronal; temperature, conductivity and total dissolved solids (TDS) of water samples were measured by Orion multiparameter - model 145. Total coliforms and E. coli were measured using the Colilert ${ }^{\circledR}$ kit method once a week before contamination,
Formatted: English (United Kingdom)

Formatted: No underline, Font color: Auto, English (United Kingdom)

Formatted: English (United Kingdom)

Formatted: No underline, Font color: Auto, English (United Kingdom)

Formatted: English (United Kingdom)

Formatted: No underline, Font color: Auto, English (United Kingdom)

Formatted: No underline, Font color: Auto, English (United Kingdom) 
and during the contamination period, samplings were done before and 24 hours after spiking the PPCPs into the ecological filters.

\subsection{PPCPs and DPs detection}

The PPCPs were extracted from the water samples using solid phase extraction (SPE) with Strata-X (Phenomenex) Polymeric Reversed Phase 200 mg/6 mL (8B-S100FCH). Each cartridge was pre-conditioned with $6 \mathrm{~mL}$ of methanol (2 times), $6 \mathrm{~mL}$ of purified water (Milli-Q), and $6 \mathrm{~mL}$ of purified water (Milli-Q) acidified with $\mathrm{HCl}$ for pH 3 per gravity. After, $300 \mathrm{~mL}$ of water ( $\mathrm{pH}$ 3.0) was passed through the cartridge sorbent at a flow rate of $5 \mathrm{~mL} \mathrm{~min}^{-1}$. The PPCPs were eluted passing $4 \mathrm{~mL}$ of methanol twice, and the volume was reduced with a gentle stream of nitrogen gas and reconstituted to $300 \mu \mathrm{L}$ with $\mathrm{MeOH}+$ Milli-Q water $(1: 1 \mathrm{v} / \mathrm{v})$. Then, the The samples were then analyzed by LC-MS/MS. Additional information about the LC-MS/MS equipment, method used and how analyses were conducted for the identification of DPs are described in the Supporting Information. Quality assurance and quality control (QA/QC) were implemented for the accuracy of the quantification of the target PPCPs. More details are also presented in the Supporting Information and Tables S3 and S4.

\subsection{Statistical analysis}

The results derived from the quantification of PPCPs were subjected to statistical analysis profiles for repeated measures, performed with PRCO GLM software from SAS. This analysis was carried out to study the effect of different type of treatments, the different times of collection, and interactions between types of treatment and times of collection. The multivariate character of analyses was previously verified by Mauchly's
Formatted: English (United Kingdom)

Formatted: No underline, Font color: Auto, English (United Kingdom)

Formatted: English (United Kingdom)

Formatted: No underline, Font color: Auto, English (United Kingdom)

Formatted: English (United Kingdom)

Formatted: No underline, Font color: Auto, English (United Kingdom)

Formatted: English (United Kingdom)

Formatted: No underline, Font color: Auto, English (United Kingdom) 
sphericity test. MANOVA analysis considered the following tests: Wilks' Lambda, Pillai's Trace, Hotelling-Lawley Trace and Roy's Greatest Root.

To determine the variability of the water quality parameters between the 22 ecological filters, the standard deviation (SD) and coefficient of variation (CV) were determined. CV was considered with high variation for values between 20 to $30 \%$ (Isensee, 1976). In addition, t-tests were as-done to examine the relationships between influent and effluent water from ecological filters; values were significant at $p<0.05$.

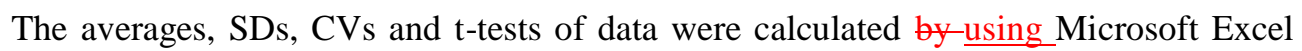
2010.

\section{Results and discussion}

\subsection{LC-MS/MS}

The adjustment of parameters for each compound and deuterates of the mass spectrometer to the individual samples of all compounds are shown in Table S5. The transition ions, or ion fragments selected in this study are in agreement with fragment ions for the same compounds described elsewhere (Miao et al., 2002; Löffler and Ternes, 2003; Rodil and Moeder, 2008; Magi et al., 2013) (Figure S2). .

\subsection{Water quality parameters}

The mean values of each water quality parameters are shown in Figure S3 and Table S6. The ecological filters met the quality parameters- except that for coliform counts, set by the Ordinance No. 2914/2011 which defines the standards of water potability in Brazil (Brasil, 2011). However, the filters had a high percentage of removal of coliforms (Figure S4) as the raw water was diluted 500 times to be count, and in the effluent of filters no dilutions were made. The filters were considered mature from $9^{\text {th }}$
Formatted: English (United Kingdom)

Formatted: No underline, Font color: Auto, English (United Kingdom)

Formatted: No underline, Font color: Auto, English (United Kingdom)

Formatted: No underline, Font color: Auto, English (United Kingdom)

Formatted: English (United Kingdom)

Formatted: No underline, Font color: Auto, English (United Kingdom)

Formatted: English (United Kingdom)

Formatted: No underline, Font color: Auto, English (United Kingdom)

Formatted: English (United Kingdom)

Formatted: No underline, Font color: Auto, English (United Kingdom)

Formatted: English (United Kingdom)

Formatted: No underline, Font color: Auto, English (United Kingdom)

Formatted: English (United Kingdom)

Formatted: No underline, Font color: Auto, English (United Kingdom) 
October ( \pm 1 month of maturation). In addition, total coliforms and E. coli were observed to have low variability among the 22 ecological filters, as SD and CV were lower than 20-30 \% (Isensee, 1976) in each water sample collected during the sampling period (Table S7), ); this demonstrating demonstrated the stability and robustness of the ecological filtration system. Thus, the removal of bacteria was not affected by the presence of PPCPs.

Formatted: English (United Kingdom)

\subsection{OceurenceOccurrence of PPCPs in the Lobo reservoir water.}

The 6 target PPCPs were identified and quantified in the Lobo reservoir water, which supplied the 22 ecological filters from September to December of 2013. The concentration of each compound detected in the filter influent water are shown in Table

1. It shows that all pharmaceuticals (i.e. ACT, DCF, NAP, IBUand IBU) were not found, at least in one sampling day, in the Lobo reservoir water. In contrast, personal care products (i.e. MEP and BP-3) were found with $100 \%$ ef frequency ${ }_{2}$ and in high concentrations compared to the pharmaceutical compounds. These results are discussed below.

Table 1: Concentrations of the compounds detected by SPE-LC-MS/MS in water samples from the Lobo reservoir.

\begin{tabular}{|c|c|c|c|c|}
\hline \multicolumn{5}{|c|}{ Raw water } \\
\hline PPCPs & Min. Conc. & Max. Conc. & Mean Conc. & Frequency \\
\hline & $\left(\mu \mathrm{g} \mathrm{L}^{-1}\right)$ & $\left(\mu \mathrm{g} \mathrm{L}^{-1}\right)$ & $\left(\mu \mathrm{g} \mathrm{L}^{-1}\right)$ & detected $(\%)$ \\
\hline $\mathrm{ACT}_{\Delta}$ & n.d. & 0.13 & 0.03 & 85.70 \\
\hline $\mathrm{DCF}_{\text {. }}$ & n.d. & 0.05 & 0.02 & 71.40 \\
\hline $\mathrm{NAP}$ & n.d. & 0.10 & 0.01 . & 85.70 \\
\hline IBU, & n.d. & 0.13 & 0.01 & 42.80 \\
\hline
\end{tabular}


MEP 0.10 1192.39 170.87 100.00$$
\text { BP-3 }
$$$$
0.32
$$$$
2.10
$$$$
1.14
$$$$
100.00
$$$$
\text { n.d.: not detected. }
$$

In the first water sampling event the concentrations of MEP and BP-3 were the

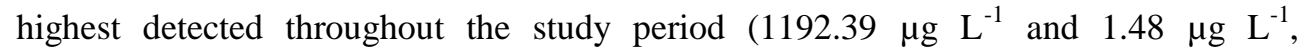
respectively). Similarly, an-investigation work done in the state of São Paulo, Brazil, found MEP at several points of the river Mogi Guaçu at which the water had on an average concentrations of $8 \mu \mathrm{g} \mathrm{L} \mathrm{L}^{-1}$, being where $27.50 \mu \mathrm{g} \mathrm{L}^{-1}$ was the highest concentration (Galinaro et al., 2015). In our study, the average concentration detected in the Lobo reservoir water of MEP detected in the Lobo reservoir water was $170.87 \mu \mathrm{g} \mathrm{L}$ ${ }^{1}$, which is much higher than the spiked concentration of $2 \mu \mathrm{g} \mathrm{L}{ }^{-1}$.

If neglecting atypical days, the average concentration detected of MEP was 0.62 $\mu \mathrm{g} \mathrm{L}{ }^{-1}$, which is similar to concentrations found from 0.005 to $79.60 \mu \mathrm{g} \mathrm{L}^{-1}$ in several water bodies worldwide e.g. India, USA, UK, China and several European countries (Benijts et al., 2004; Loraine and Pettigrove, 2006; Peng et al., 2008; Blanco et al., 2009; Pedrouzo et al., 2009; Jonkers et al., 2010; Ramaswamy et al., 2011; Renz et al., 2013; Haman et al., 2015). However, the average concentration of BP-3 in the Lobo reservoir water was $1.14 \mu \mathrm{g} \mathrm{L}^{-1}$, highterhigher than the other published work. For example, in lakes in Switzerland takes-the concentration of BP-3 was found to range from $<2$ to $125 \mathrm{ng} \mathrm{L}^{-1}$ (Poiger et al., 2004). In Brazil, Silva et al. (2013) reported $<2 \mathrm{ng}$ $\mathrm{L}^{-1}$ in Araraquara city, São Paulo. It has also been found in several countries such as Japan, Spain, South Korea, UnitedUnited Kingdom, ameng others etc. at concentrations from $<0.30$ to $103 \mathrm{ng} \mathrm{L}^{-1}$ (Kim and Choi, 2014).

ACT was found in concentrations ranging from $0.01 \mu \mathrm{g} \mathrm{L}^{-1}$ to $0.13 \mu \mathrm{g} \mathrm{L}^{-1}$ over the study period, with an average concentration of $0.04 \mu \mathrm{g} \mathrm{L}^{-1}$. In other studies
Formatted: No underline, Font color: Auto, English (United Kingdom)

Formatted: English (United Kingdom)

Formatted: No underline, Font color: Auto, English (United Kingdom)

Formatted: English (United Kingdom)

Formatted: No underline, Font color: Auto, English (United Kingdom)

Formatted: English (United Kingdom)

Formatted: No underline, Font color: Auto, English (United Kingdom)

Formatted: English (United Kingdom)

Formatted: No underline, Font color: Auto, English (United Kingdom)

Formatted: English (United Kingdom)

Formatted: No underline, Font color: Auto, English (United Kingdom)

Formatted: English (United Kingdom)

Formatted: No underline, Font color: Auto, English (United Kingdom)

Formatted: English (United Kingdom)

Formatted: No underline, English (United Kingdom)

Formatted: English (United Kingdom)

Formatted: No underline, Font color: Auto, English (United Kingdom)

Formatted: English (United Kingdom)

Formatted: No underline, Font color: Auto, English (United Kingdom)

Formatted: English (United Kingdom)

Formatted: No underline, Font color: Auto, English (United Kingdom)

Formatted: English (United Kingdom)

Formatted: No underline, Font color: Auto, English (United Kingdom)

Formatted: No underline, Font color: Auto, English (United Kingdom)

Formatted: English (United Kingdom)

Formatted: No underline, Font color: Auto, English (United Kingdom)

Formatted: No underline, Font color: Auto, English (United Kingdom)

Formatted: No underline, Font color: Auto, English (United Kingdom)

Formatted: English (United Kingdom)

Formatted: No underline, Font color: Auto, English (United Kingdom) 
conducted in Brazil, Almeida and Weber- $_{-}$(2009) reported ACT concentrations in Billings dam between 0.30 and $10.30 \mathrm{ng} \mathrm{L}^{-1}$. Montagner and Jardim, (2011) found 13.44 $n g \mathrm{~L}^{-1}$ in water samples from the basin of Atibaia, and Oliveira, (2014) reported the concentration 11-531 ng $\mathrm{L}^{-1}$ in the Guarapiranga dam. In other countries, ACT was found with a mean concentration of $0.05 \mu \mathrm{g} \mathrm{L} \mathrm{L}^{-1}$ (Bound and Voulvolis, 2006; Gros et al., 2006). ACT is one of the most frequently found drugs in surface water, wastewater and drinking water (Parolini et al., 2009). Henschel et al. (1997) classified this compound as harmful to aquatic organisms, based on some ecotoxicological tests with different biological models such as bacteria, algae, cladocerans and fish.

DCF is among the 10 compounds most often found in aquatic ecosystems (Sotelo et al., 2014). In our work its average detected concentration was $0.02 \mu \mathrm{g} \mathrm{L}^{-1}$, and it was not found or was below the detection limit in 3 of the 9 samples taken. In Brazil, DCF was also found in the Billings dam in concentrations from 8.10 to 394.50 ng $\mathrm{L}^{-1}$ (Almeida and Weber, 2009), the concentration in the Guarapiranga dam was between 6 to $36 \mathrm{ng} \mathrm{L}^{-1}$ (Oliveira, 2014), and in Rio de Janeiro it was found at a concentration of $60 \mathrm{ng} \mathrm{L}^{-1}$ (Stumpf et al., 1999). In Germany, the concentration reached $600 \mathrm{ng} \mathrm{L}^{-1}$ (Heberer, 2002). In addition, NAP and IBU, are also amongst the most frequent drugs found in water bodies, and were found with an average concentration of $0.03 \mu \mathrm{g} \mathrm{L}^{-1}$ and $0.06 \mu \mathrm{g} \mathrm{L}^{-1}$, respectively. However, the results agree with other Brazilian studies that found these compounds in the Billings dam (10 to $78.20 \mathrm{ng} \mathrm{\textrm {L } ^ { - 1 }}$ ) (Almeida and Weber, 2009), and Rio de Janeiro $\left(<0.01 \mu \mathrm{g} \mathrm{L}^{-1}\right)($ Stumpf et al., 1999). In our study, NAP was not found in one of the sampling days, and was below the limit of quantification in 3 -three of the sampling days. Also, IBU was not found in 4 four of the sampling days, and was below the limit of quantification in one of them.
Formatted: English (United Kingdom)

Formatted: No underline, Font color: Auto, English (United Kingdom)
Formatted: No underline, Font color: Auto, English (United Kingdom)

Formatted: No underline, Font color: Auto, English (United Kingdom)

Formatted: English (United Kingdom) 
According to meteorological data collected at the climatological station of the

Centre for Water Resources and Environmental Studies (CRHEA in Portuguese), that which follows the rules of the World Meteorological Organization, on the day of the first collection, it rained an average of $55.40 \mathrm{~mm}$. However, the reservoir has several houses en-in its surroundings and high recreational and tourist activities, a fact that has been described previously (Calijuri and Tundisi, 1990) to have resulted in environmental changes eaused-by human activities such as deforestation, dumping of domestic sewage and fertilizers used in some agriculture areas. The first water sampling took place on 11.04.2013 (Monday), and, interestingly, on the previous weekend there was a national bank holiday. Therefore, there was a likely increase in the use of the reservoir for bathing, and its surroundings for recreational activities - . This combined with and-the potential wastewater discharge by the ranches that border the reservoir might have contributed to the increase in the concentration of the target compounds such as DCF $\left(0.05 \mu \mathrm{g} \mathrm{L}^{-1}\right)$, NAP $\left(0.10 \mu \mathrm{g} \mathrm{L}^{-1}\right)$, IBU $\left(0.13 \mu \mathrm{g} \mathrm{L}^{-1}\right)$, and especially MEP $\left(1192.39 \mu \mathrm{g} \mathrm{L}^{-1}\right)$

\subsection{Degradation Products}

The DP extractions were performed for each mass found for all DPs of each PPCP compound, and those that were detected in the samples, were selected for fragmentation analysis. The selected masses were: $\mathrm{m} / \mathrm{z} 292$ and $\mathrm{m} / \mathrm{z} 278$ (DP of DCF), $m / z 201$ (DP of MEP), $m / z 282$ (DP of DCF), $m / z 185$ (DP of MEP), $m / z 245$ and $m / z$ 215 (DP of BP-3), $\mathrm{m} / \mathrm{z} 231$ (DP of BP-3), and they were-based on the literature described in Section 1.1 of the Supporting Information. The ion scanning experiments for the samples were carried out, and by through analysing the spectra, it was observed that the same compounds detected in the reservoir water samples, at all times and days
Formatted: No underline, Font color: Auto, English (United Kingdom)

Formatted: English (United Kingdom)

Formatted: No underline, Font color: Auto, English (United Kingdom)

Formatted: English (United Kingdom)

Formatted: No underline, Font color: Auto, English (United Kingdom) 
of sampling ${ }_{2}$ were the same found in the filter effluent samples. This suggests the same compounds, which were expected to be identified as DPs generated by the treatment during ecological filtration, were already present in the incoming water (Lobo reservoir). This is confirmed by the presence of the background concentration of each target compound in the reservoir water (Table 1).

The selected masses $\mathrm{m} / z 292$ and 245, DPs of DCF and BP-3, respectively, were found in all samples and were-further analysed. The DP $291(\mathrm{~m} / \mathrm{z} 292)$ showed fragments ion $274\left(\mathrm{C}_{14} \mathrm{H}_{9} \mathrm{NO}_{3} \mathrm{Cl}\right), 218\left(\mathrm{C}_{12} \mathrm{H}_{9} \mathrm{NOCl}\right)$ and $150\left(\mathrm{C}_{11} \mathrm{H}_{4} \mathrm{~N}\right)$ (Figure 1a). The DP $244(m / z, 245)$ was presented as the principal fragments $217\left(\mathrm{C}_{13} \mathrm{H}_{13} \mathrm{O} 3\right), 199$ $\left(\mathrm{C}_{13} \mathrm{H}_{11} \mathrm{O}_{2}\right), 189\left(\mathrm{C}_{12} \mathrm{H}_{13} \mathrm{O}_{2}\right)$ and $157\left(\mathrm{C}_{11} \mathrm{H}_{9} \mathrm{O}\right)$ (Figure 1b). Both compounds are consistent with the literature (e.g. Wiesenberg-Boettcher et al, 1991; Agüera et al., 2005; Gong et al., 2015), and have been detected in water bodies. It is worth noting that the DPs were only identified but not quantified by the method, as there was no sufficient sensitivity at trace levels. Therefore, further research on quantification of the DP compounds in the water reservoir and the effluent of the ecological filters is recommended.

(a) +MS2 (292.00) CE (25): Exp 6, 4.331 to $6.393 \mathrm{~min}$ from ... Max. $3288.2 \mathrm{cps}$.

$\geq$ $\mp 3000$ is

$\subset 2000$

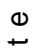
$\simeq 1000$

$\infty$

으

0
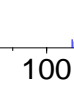

134.

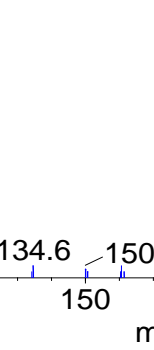

\section{4}

Formatted: English (United Kingdom)

Formatted: No underline, Font color: Auto, English (United Kingdom)

Formatted: English (United Kingdom)

Formatted: No underline, Font color: Auto, English (United Kingdom)

Formatted: English (United Kingdom) 
<smiles>O=C1C=CC(=Nc2c(O)cccc2Cl)C(CC(=O)O)=C1</smiles>

$\mathrm{m} / \mathrm{z} 292$<smiles>O=[C]CC1=CC(=O)C=CC1=Nc1c(O)cccc1Cl</smiles><smiles>[C]#C</smiles><smiles>[C]1=CC=C2C1=Nc1ccccc12</smiles>
$\mathrm{m} / \mathrm{z} 150$
$-\mathrm{CO}$<smiles>CC1=CC(=O)C=CC1=Nc1c(O)cccc1Cl</smiles>

$m / z 246$

$-\mathrm{co}$

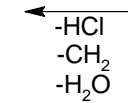<smiles>[CH2]C1=CC=CC1=Nc1c(O)cccc1Cl</smiles>

$m / z 218$ b)

I $+\mathrm{M} \overline{\mathrm{S}} 2$ (245.00) CE (25): $\operatorname{Exp} 12,4.640$ to $5.550 \mathrm{~min}$ fro... ( 3742

Max. 3742.4 cps.

245.3
@
Ð

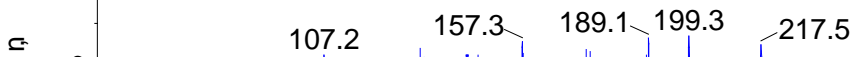

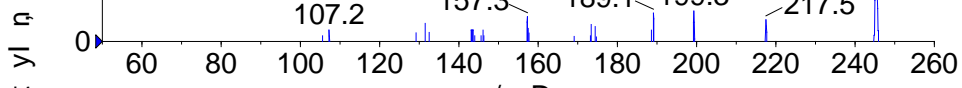

Formatted: No underline, Font color: Auto, English (United Kingdom)

Formatted: English (United Kingdom) Formatted: English (United Kingdom) 
<smiles>COc1ccc(C(=O)c2cccc(O)c2)c(O)c1</smiles><smiles>CC(C)(C)O</smiles><smiles>COc1ccc(-c2ccccc2)c(O)c1</smiles>

$\mathrm{m} / \mathrm{z} 217$<smiles>COc1ccc(-c2cccc(O)c2)cc1</smiles><smiles>COc1ccc(C2=CCC(=O)C=C2)c(O)c1</smiles>

$\checkmark-\mathrm{CO}$<smiles>OCC(O)C1=C(O)C=[C+]C=C1</smiles>

$\mathrm{m} / \mathrm{z} 157$

$$
[
$$<smiles>COc1ccc(C2=CC[CH-]C2)c(O)c1</smiles>
ecological filters: a) DP of DCF; b) DP of BP-3.

\subsection{Removal of PPCPs by the ecological filters} receiving the mix solution (Mix).

\subsubsection{Removal of pharmaceuticals}

\section{Analgesic (ACT)}

Figure 1: Identified fEragment ions spectra of the degradation products (DPs) identified, and propesal-proposed fragmentation mechanism for both water reservoir and effluent of the

The mean removal efficiencies of the selected PPCPs are discussed below by class of compounds i.e. pharmaceuticals (Figures 2 and 3) and personal care products (Figure 4). AlseAdditionally, the results are presented by the types of filter i.e. filters receiving individual compound (FEco), control filter (Control) and three filters

The efficiency of ecological filters to remove ACT in this study was on average $81 \%$ (Figure 2) and this agrees well with other research using a similar filtration
Formatted: English (United Kingdom)

Formatted: No underline, Font color: Auto, English (United Kingdom)

Formatted: No underline, Font color: Auto, English (United Kingdom)

Formatted: English (United Kingdom)

Formatted: No underline, Font color: Auto, English (United Kingdom)

Formatted: English (United Kingdom)

Formatted: No underline, Font color: Auto, English (United Kingdom)

Formatted: English (United Kingdom)

Formatted: No underline, Font color: Auto, English (United Kingdom)

Formatted: English (United Kingdom)

Formatted: No underline, Font color: Auto, English (United Kingdom)

Formatted: English (United Kingdom)

Formatted: No underline, Font color: Auto, English (United Kingdom) 
system. For example, Erba et al. (2012) reported $80 \%$ removal of $2 \mu \mathrm{g} \mathrm{L}^{-1}$ of ACT by an ecological filter. On the other hand, Li et al. (2018) reported removals above 78-67 $\%$ of $25 \mu \mathrm{g} \mathrm{L}^{-1}$ of ACT using GAC-sandwich SSF, while Pompei et al. (2017) found 65 $\%$ removal of $2 \mu \mathrm{g} \mathrm{L}^{-1} \mathrm{ACT}$ using household SSF. Our higher removal values might have been due to the fact that the filters were located outdoors and not in laboratory as per Pompei et al. (2017) and Li et al. (2018). Although laboratory tests attempt to simulate natural conditions, these tests do not consider environmental changes such as microbial community diversity, quantity, and climatic conditions, which evolve over time and space in nature (Ranjard et al., 2013). Therefore, biological degradation processes in environmental conditions are influenced by other variables that are present in natural environments (Francois et al., 2016). Because of the variability between laboratory and environmental conditions, it is suggested to carry out research in natural conditions to produce more authentic real application results. Other-Another reason for the difference in results could be the sand uniformity coefficient used in each filter. Erba et al. (2012) worked with _a filter sand of similar uniformity coefficient (effective size $=0.25 \mathrm{~mm}$, uniformity coefficient $=2-3$ ) to our swork, while Pompei et al. (2017) (effective size $=0.210 \mathrm{~mm}$, uniformity coefficient $=$ 1.4) and Li et al. (2018) (effective size of $0.6 \mathrm{~mm}$, uniformity coefficient $=1.4$ ) had smaller values for the uniformity coefficient. These confirm the findings by $\mathrm{Di}$ Bernardo and Rivera (1996) who found that the biological layer (i.e. schmutzdecke) was larger in filters containing sand with a larger uniformity coefficient. Therefore, it is possible that the biological layer in our work was larger than the ones in Pompei et al. (2017) and Li et al. (2018), leading to a larger removal of the target PPCPs. Campos et al. (2002) suggested that the schmutzdecke is responsible for significant inputs of carbon substrates to the underlying sand layer supporting interstitial microbial growth. These 
results confirm that biodegradation is a major mechanism for ACT removal (Onesios et al., 2009; Lin et al., 2010).

Comparing with other water treatment processes The ecological filters were less efficient than such as AOP systemss such as, fenton, UV and ozone oxidations which were shown to remove reached-100\%-removal of ACT-when using synthetic water (Tayo et al., 2018). However, the high cost of these technologies and the use of chemicals during the treatment makes them not very unattractive when compared to ecological filters which have presented very good levels of ACT removals. Finally, the statistical analysis MANOVA showed no significant difference $(p>0.05)$ between the type of filter (Control, FEco or Mix) and collection times (3, 6 and 24 hours), although the Control filter had a lower percentage of removal compared to the FEco and Mix filters (Figure 2). The error bars were higher in the Control filter, because there were no triplicates of this filter, but only for FEco and Mix filters (Figure 2).

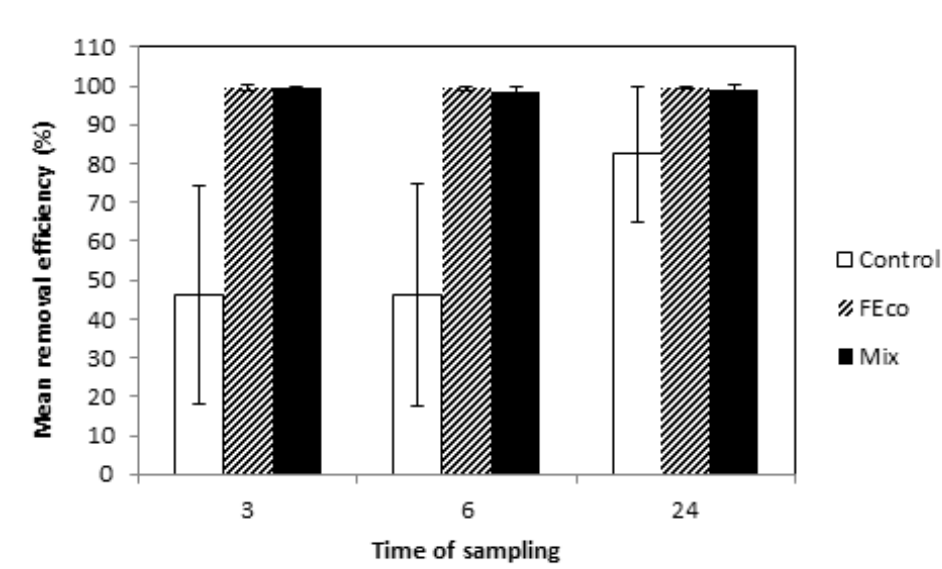

Figure 2: Mean removal $(\%)$ of ACT by ecological filtration, in Control filter $(\mathrm{n}=9)$, $\operatorname{FEco}(\mathrm{n}=27)$ and $\operatorname{Mix}(\mathrm{n}=27)$.

Anti-inflamatoryinflammatory (DCF, IBU, NAP),
Formatted: English (United Kingdom)

Formatted: No underline, Font color: Auto, English (United Kingdom)

Formatted: No underline, Font color: Auto, English (United Kingdom)

Formatted: No underline, Font color: Auto, English (United Kingdom)

Formatted: No underline, Font color: Auto, English (United Kingdom)

Formatted: No underline, Font color: Auto, English (United Kingdom)

Formatted: No underline, Font color: Auto, English (United Kingdom)

Formatted: No underline, Font color: Auto, English (United Kingdom)

Formatted: English (United Kingdom)

Formatted: English (United Kingdom)

Formatted: No underline, Font color: Auto, English (United Kingdom)

Formatted: English (United Kingdom)

Formatted: No underline, Font color: Auto, English (United Kingdom)

Formatted: English (United Kingdom) 
The removal of DCF by ecological filters were was on average $91 \%$, confirming previous findings of $94 \%$ DCF removal by ecological filters elsewhere (Erba et al., 2012). On the other hand, Rigobello et al. (2013) found that there was no removal of DCF by conventional SSF, but however, their experiment was conducted using synthetic water. Therefore ${ }_{2}$ it is possible that there was no ideal formation of the biofilm which is easily formed using natural water from lakes and/or rivers, where there is already an aquatic biota that can colonize the top of the filter sand. Also, DCF removal by WWTPs showed large differences in removals, e.g. $17 \%$ (Heberer, 2002), $69 \%$ (Ternes, 1998), and $100 \%$ (Thomas and Foster, 2004), which this may be due to differences in temperature and climate (Delpla et al., 2009). Now, $\underline{\text { When }}$ comparing this to advanced treatment, the ecological filters provided similar DCF removal $(91 \%)$ to AOPs applying ozonation and UV oxidation (100\%), and fenton oxidation (> $85 \%$ ) (Tayo et al., 2018). The results again demonstrate the benefit of using ecological filtration without the need of chemicals, and confirm that biodegradation is an important mechanism for DCF removal (Onesios et al., 2009).

For IBU, the ecological filters removed on average $99 \%$ of it. This is in agreenmentagreement with Erba et al. (2012) who found IBU removal of $76 \%$ by ecological filters, and Winkler et al. (2001) who evaluated the biodegradation of IBU by biofilm from surface waters and observed a rapid degradation up to $90 \%$. Yet for NAP, the ecological filters removed on average $97 \%$ of it. This; this result also agrees with Erba et al. (2012) who found NAP removal of $87 \%$ using ecological filters. In eomparasioncomparison with advanced processes, our results show that the ecological filter is capable of also removing IBU and NAP with similar efficiencies to AOPs using ozonation (> $99 \%$ ), UV oxidation (100\%) and fenton oxidation (> $50 \%$ ) (Tayo et al., 2018).
Formatted: No underline, Font color: Auto, English (United Kingdom)

Formatted: No underline, Font color: Auto, English (United Kingdom)

Formatted: English (United Kingdom)

Formatted: No underline, Font color: Auto, English (United Kingdom)

Formatted: No underline, Font color: Auto, English (United Kingdom)

Formatted: No underline, Font color: Auto, English (United Kingdom) 

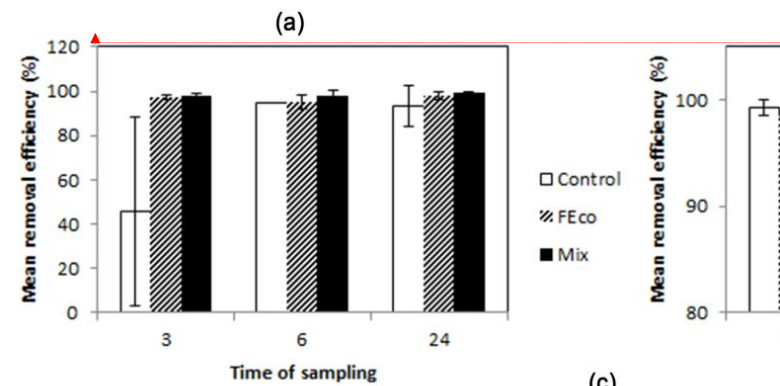

(b)

Formatted: English (United Kingdom)

Figure 3: Mean removal of: a) DCF; b) IBU; c) NAP, in Control filter ( $n=9)$, FEco (n

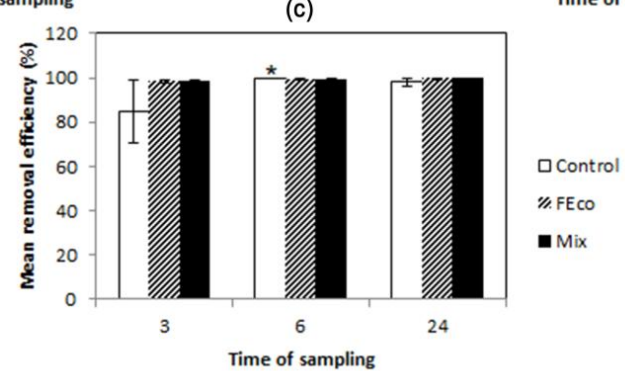

$=27)$ and $\operatorname{Mix}(\mathrm{n}=27)$. The * corresponds to the situations when, in one or more

samples of the raw water, the compounds were not detected, thereby disabling the

calculation of the standard deviation and consequently the error.

Formatted: English (United Kingdom)

Formatted: No underline, Font color: Auto, English (United Kingdom) effluent concentration significantly different to the others $(p=0.04)$ between collection times. However, the specific analysis of contrasts (Table S8) did not show the difference indicated by the general test. In this case, it was considered the difference between the mean concentrations in at the times 6 and 24 hours, since they were, respectively, the highest and the lowest sample means (3 hours: $0.04 \mu \mathrm{g} \mathrm{L}^{-1}, 6$ hours: $0.06 \mu \mathrm{g} \mathrm{L} \mathrm{L}^{-1}, 24$ hours: $\left.0.02 \mu \mathrm{g} \mathrm{L}^{-1}\right)$. For IBU, MANOVA shows no significant difference $(p>0.05)$ between the types of filters (Control, FEco and Mix filters), 
between the sampling times (3, 6 and 24 hours), and between the types of filter and sampling time (Figure 3b). For NAP, MANOVA shows that there were also no diferencesdifferences between the types of filters (Control, FEco or Mix filters).

However, the tests indicate there was at least one concentration different in relation to the others at times 3,6 and 24 hours $(p=0.01)$. The specific analysis of contrasts identified that the difference was between 3 and 24 hours (Table S7). At the sampling time of 24 hours the effluent concentration of NAP was lower than in the two previous sampling times, with the values of the sample means being as $0.02 \mu \mathrm{g} \mathrm{L}^{-1}$ in the time of 3 hours; $0.01 \mu \mathrm{g} \mathrm{L}^{-1}$ at 6 hours; and $0.001 \mu \mathrm{g} \mathrm{L}^{-1}$ at 24 hours after the contamination of the filters.

\subsubsection{Removal of personal care products}

The removal of personal care products by ecological filters was lower than the removal of pharmaceutical compounds.And; this may have been due to the fact MEP and BP-3 were found with high concentrations in the Lobo reservoir water as discussed above. However, MEP and BP-3 had similar removals, being of on average $70 \%$ and $71 \%$, respectively (Figure 4). On the other hand, Pompei et al. (2017) reported $100 \%$ removal of $2 \mu \mathrm{g} \mathrm{L}^{-1}$ of MEP and BP-3 by household SSF. However, these compounds were not found in the water of Regent's Park as identified in the Lobo reservoir water. Verlicchi et al. (2014) performed a literature review on the removal of personal care products by wetlands in Europe, North America and Asia, showing that removal was influenced mainly by redox potential, temperature, hydraulic retention time and affluent concentration of the compound. And this This may explain the difference between the findings by Pompei et al. (2017) and ours. Furthermore, when eomparing $\underline{\text { compared }}$ with other treatment processes; the removals of MEP and BP-3 were-was not as high as
Formatted: No underline, Font color: Auto, English (United Kingdom)

Formatted: English (United Kingdom)

Formatted: No underline, Font color: Auto, English (United Kingdom)

Formatted: English (United Kingdom)

Formatted: No underline, Font color: Auto, English (United Kingdom) 
those achieved by AOPs (Tayo et al., 2018). However, it is hightlightedshould be noted that Gomes et al. (2017) reported the generation of toxic by-products of paraben which

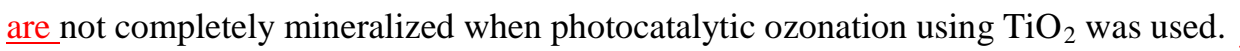

Finally, despite the differences in removals of MEP in the Control filter in relation to the other filters (Figure 4b), MANOVA tests show that there were no difference between the treatments (Control, FEco or Mix filters) $(p>0.05)$, between sampling times of 3, 6 and 24 hours $(p=0.35)$, and between types of filter and sampling time $(p>0.05)$. For the BP-3, the MANOVA tests show there were no diferencedifference between the treatments (Control, FEco or Mix filters) $(p>0.05)$, but there was a difference between sampling time $(p=0.02)$. The specific analysis of contrasts identified that the difference was between 3 hours $\left(0.99 \mu \mathrm{g} \mathrm{L}^{-1}\right)$ and 24 hours $\left(0.35 \mu \mathrm{g} \mathrm{L}^{-1}\right)$ (Table S7).
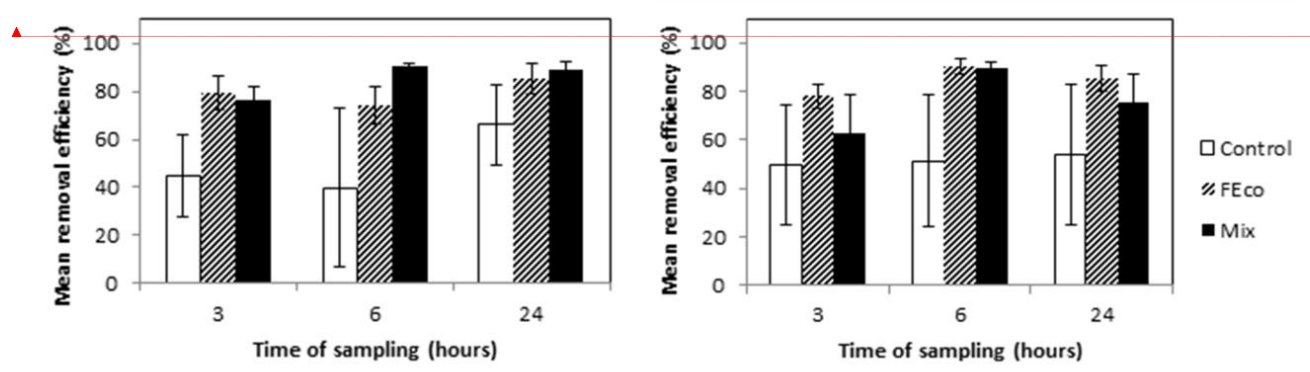

Figure 4: Mean removals of personal care products for a) BP-3 and b) MEP, in Control filter $(\mathrm{n}=9)$, FEco $(\mathrm{n}=27)$ and Mix $(\mathrm{n}=27)$.

\section{Conclusions}

The results of water quality parameters indicated that the water treated by the ecological filters was within the standard of potability from Brazil. It is noted that filtered water needs to be disinfected for human consumption to totally remove coliforms.
Formatted: English (United Kingdom)

Formatted: No underline, Font color: Auto, English (United Kingdom)

Formatted: No underline, Font color: Auto, English (United Kingdom)

Formatted: English (United Kingdom)

Formatted: English (United Kingdom)

Formatted: No underline, Font color: Auto, English (United Kingdom)

Formatted: English (United Kingdom)

Formatted: No underline, Font color: Auto, English (United Kingdom)

Formatted: English (United Kingdom) Formatted: No underline, Font color: Auto, English (United Kingdom)

Formatted: English (United Kingdom) 
The target PPCPs were identified in the Lobo reservoir water in the range of $\mu \mathrm{g}$ $\mathrm{L}^{-1}$. The personal care products were detected with $100 \%$ ef frequency in samples, and in high concentrations compared to the pharmaceutical compounds. These results were attributed to recreational use of the reservoir and wastewater effluent discharges.

Two DPs (DCF and BP-3) were identified in the reservoir and effluent filters water samples. The fragment ions were identified, and a degradation path for both compounds were proposed. To evaluate their removal of them-by ecological filters $\underline{a}$ further investigation on quantification of the DP compounds are is recommended.

Ecological filters removed more of the The pharmaceutical compounds (81 to $99 \%$ ) were better removed by the ecological filters-than the personal care products ( 70 to 71 $\%)$. The statistical tests by MANOVA did not show significant differences for any of the compounds in relation to the type of filter (Control, FEco or Mix filters) ${ }_{2}$ showing the robustness of the ecological filtration system. Results showed that the filters are resilient to an individual compound as to their mixture. Some compounds (DCF, NAP, BPand BP-3) showed differences between some of the sampling times, but this was probably due to the variation of background contamination in the reservoir water and the spiked contamination of $2 \mu \mathrm{g} \mathrm{L}^{-1}$.

In eomparasioncomparison, with other advanced technologies (e.g. ozone, fenton, UV irradiation) that may remove $100 \%$ of our target PPCPs, the authors believe that with eptmisedoptimised operational conditions, ecological filtration offers a low cost and chemical free treatment option for the effective PPCP removal in decentralized systems.

\section{Acknowledgements}

Formatted: No underline, Font color: Auto, English (United Kingdom)

Formatted: No underline, Font color: Auto, English (United Kingdom)

Formatted: English (United Kingdom)

Formatted: No underline, Font color: Auto, English (United Kingdom)

Formatted: No underline, Font color: Auto, English (United Kingdom)

Formatted: No underline, Font color: Auto, English (United Kingdom)

Formatted: No underline, Font color: Auto, English (United Kingdom)

Formatted: No underline, Font color: Auto, English (United Kingdom)

Formatted: English (United Kingdom) Formatted: No underline, Font color: Auto, English (United Kingdom)

Formatted: No underline, Font color: Auto, English (United Kingdom)

Formatted: No underline, Font color: Auto, English (United Kingdom)

Formatted: No underline, Font color: Auto, English (United Kingdom)

Formatted: English (United Kingdom)

Formatted: No underline, Font color: Auto, English (United Kingdom)

Formatted: No underline, Font color: Auto, English (United Kingdom)

Formatted: No underline, Font color: Auto, English (United Kingdom)

Formatted: No underline, Font color: Auto, English (United Kingdom)

Formatted: English (United Kingdom)

Formatted: No underline, Font color: Auto, English (United Kingdom)

Formatted: English (United Kingdom) 
This research was financially supported by the São Paulo Research Foundation, Brazil (FAPESP) n. 2012/21981-7, and Dr Caroline Moço Erba Pompei was supported by FAPESP through the scholarship n. 2011/21666-1. Authors thanks also the project n. 2008/10449-7 (FAPESP) for the LC-MS/MS.

\section{References}

Agüera, A., Pérez Estrada, L. A., Ferrer, I., Thurman, E. M., Malato, S., \& Fernández-Alba, A. R., 2005. Application of time-of-flight mass spectrometry to the analysis of phototransformation products of diclofenac in water under natural sunlight. Journal of Mass Spectrometry, 40(7), 908-915. doi: 10.1002/jms.867

Almeida, G. A. D., Weber, R. R., 2009. Fármacos na represa Billings. Revista Saúde e Ambiente, 6(2), 7-13.

Andrés-Costa, M. J., Rubio-López, N., Suárez-Varela, M. M., \& Pico, Y., 2014. Occurrence and removal of drugs of abuse in Wastewater Treatment Plants of Valencia (Spain).

Environmental pollution, 194, 152-162. doi: 10.1016/j.envpol.2014.07.019.

Bellamy, W.D.; Hendricks. D.W. and Longsdon, G.S., 1985. "Slow and Filtration” Journal of the American Water Works Association. 77(12), p.62-66.

Benijts, T., Lambert, W., \& De Leenheer, A., 2004. Analysis of multiple endocrine disruptors in environmental waters via wide-spectrum solid-phase extraction and dual-polarity ionization

LC-ion trap-MS/MS. Analytical chemistry, 76(3), 704-711. doi:10.1021/ac035062x

Beretelkamp, C. Reungoat, J., Cornelissen, E.R., Singhal, N., Reynisson, J., Cabo, A.J., Van

Der Hoek, J.P., Verliefd, A.R.D., 2014. Sorption and biodegradation of organic

micropollutants during river bank filtration: a laboratory column study. Water research, 52,

231-241. doi: 10.1016/j.watres.2013.10.068

Blanco, E., del Carmen Casais, M., del Carmen Mejuto, M., \& Cela, R., 2009. Combination of off-line solid-phase extraction and on-column sample stacking for sensitive determination of
Formatted: No underline, Font color: Auto, English (United Kingdom)

Formatted: English (United Kingdom)

Formatted: No underline

Formatted: No underline, English

(United Kingdom)

Formatted: No underline, Font color: Auto, English (United Kingdom)

Formatted: No underline, English (United Kingdom)

Formatted: English (United Kingdom)

Formatted: No underline, Font color: Auto, English (United Kingdom)

Formatted: No underline, Font color: Auto, Portuguese (Brazil)

Formatted: No underline, Font color: Auto

Formatted: No underline, Font color: Auto, English (United Kingdom)

Formatted: English (United Kingdom)

Formatted: No underline, Font color: Auto, English (United Kingdom)

Formatted: English (United Kingdom)

Formatted: No underline, Font color: Auto, English (United Kingdom)

Formatted: English (United Kingdom)

Formatted: No underline, Font color: Auto, English (United Kingdom)

Formatted: English (United Kingdom)

Formatted: No underline, Font color: Auto, English (United Kingdom) 
parabens and p-hydroxybenzoic acid in waters by non-aqueous capillary electrophoresis.

Analytica chimica acta, 647(1), 104-111. doi:10.1016/j.aca.2009.05.024

Bound, J. P., \& Voulvoulis, N., 2006. Predicted and measured concentrations for selected pharmaceuticals in UK rivers: implications for risk assessment. Water Research, 40(15), 2885-2892. doi:10.1016/j.watres.2006.05.036

Brasil, 2011. Ministério da Saúde. Portaria n 2.914, de 12 de dezembro de 2011. Dispõe sobre os procedimentos de controle e de vigilância da qualidade da água para consumo humano e seu padrão de potabilidade. Diário Oficial da União [da] República Federativa do Brasil. Seção 1, p. 26.

Calijuri, M. C., \& Tundisi, J. G., 1990. Limnologia comparada das represas do Lobo (Broa) e Barra Bonita-Estado de São Paulo: mecanismos de funcionamento e bases para o gerenciamento. Revista Brasileira de Biologia, 50(4), 893-913.

Camacho-Munoz, D., Martín, J., Santos, J. L., Alonso, E., Aparicio, I., De la Torre, T., \& Malfeito, J. J., 2012. Effectiveness of three configurations of membrane bioreactors on the removal of priority and emergent organic compounds from wastewater: comparison with conventional wastewater treatments. Journal of Environmental Monitoring, 14(5), 14281436. doi:10.1039/C2EM00007E

Campos, L.C., M.F.J. Su, Graham N.J.D \& Smith, S.R. 2002 Biomass development in slow sand filters. Water Research, International: 36(18), 4543-4551. doi: 10.1016/S00431354(02)00167-7.

Chen, D. Y., Guo, X. F., Wang, H., \& Zhang, H. S., 2015. The natural degradation of benzophenone at low concentration in aquatic environments. Water Science and Technology, 72(4), 503-509. doi:10.2166/wst.2015.221

Chen, Y., Vymazal, J., Březinová, T., Koželuh, M., Kule, L., Huang, J., \& Chen, Z., 2016. Occurrence, removal and environmental risk assessment of pharmaceuticals and personal care products in rural wastewater treatment wetlands. Science of the Total Environment, 566, 1660-1669. doi:10.1016/j.scitotenv.2016.06.069
Formatted: No underline, Font color: Auto, English (United Kingdom)

Formatted: No underline, Font color: Auto

Formatted: No underline, Font color Auto

Formatted: No underline, Font color: Auto, English (United Kingdom)

Formatted: English (United Kingdom)

Formatted: No underline, Font color: Auto, English (United Kingdom)

Formatted: English (United Kingdom)

Formatted: No underline, Font color: Auto, English (United Kingdom)

Formatted: English (United Kingdom)

Formatted: No underline, Font color: Auto, English (United Kingdom)

Formatted: English (United Kingdom) 
Daughton, C. G., \& Ternes, T. A., 1999. Pharmaceuticals and personal care products in the environment: agents of subtle change? Environmental health perspectives, 107 (Suppl 6), 907. doi:10.1289/ehp.99107s6907.

Delpla, I., Jung, A. V., Baures, E., Clement, M., \& Thomas, O., 2009. Impacts of climate change on surface water quality in relation to drinking water production. Environment international, 35(8), 1225-1233. doi:10.1016/j.envint.2009.07.001.

Dévier, M. H., Mazellier, P., Ait-Aissa, S., \& Budzinski, H., 2011. New challenges in environmental analytical chemistry: identification of toxic compounds in complex mixtures. Comptes Rendus Chimie, 14(7-8), 766-779. doi:10.1016/j.crci.2011.04.006

Di Bernardo, L., 1993. Métodos e técnicas de tratamento de água. In Métodos e técnicas de tratamento de água. Abes.

Di Bernardo, L., \& Rivera, E. 1996. Influence of sand uniformity coefficient on slow sand filtration performance. Advances in Slow Sand and Biological Filtration, 179-188.

Ellis, J. B., 2006. Pharmaceutical and personal care products (PPCPs) in urban receiving waters. Environmental pollution, 144(1), 184-189. doi:10.1016/j.envpol.2005.12.018

Erba, C. M., Tangerino, E. P., Carvalho, S. L. D., \& Isique, W. D., 2012. Remoção de diclofenaco, ibuprofeno, naproxeno e paracetamol em filtro ecológico seguido por filtro de carvão granular biologicamente ativado. Engenharia Sanitária e Ambiental, 137-142. doi:10.1590/S1413-41522012000200002.

Erba, C. M.; Tangerino, E.P.; Isique, W. D.; Campos, L. C. , 2014. Removal of antiinflammatory compounds by ecological filtration. In: Nobutada Nakamoto, Nigel Graham, M. Robin Collins and Rolf Gimbel. (2014) (Org.). Progress in slow sand and alternative biofiltration process. 1ed.: IWA publishing. v. 5, cap 19, p. 147-152.

Escolà Casas, M., Bester, K., 2015. Can those organic micro-pollutants that are recalcitrant in activated sludge treatment be removed from wastewater by biofilm reactors (slow sand filters)?. Science of the Total Environment, 506, 315-322. doi:10.1016/j.scitotenv.2014.10.113
Formatted: No underline, Font color: Auto, English (United Kingdom)

Formatted: English (United Kingdom)

Formatted: No underline, Font color: Auto, English (United Kingdom)

Formatted: English (United Kingdom)

Formatted: No underline, Font color: Auto, English (United Kingdom)

Formatted: No underline, Font color: Auto

Formatted: No underline, Font color: Auto

Formatted: No underline, Font color: Auto, English (United Kingdom)

Formatted: English (United Kingdom)

Formatted: No underline, Font color: Auto, English (United Kingdom)

Formatted: No underline, Font color: Auto

Formatted: No underline, Font color: Auto, English (United Kingdom)

Formatted: English (United Kingdom)

Formatted: No underline, Font color: Auto, English (United Kingdom)

Formatted: English (United Kingdom)

Formatted: No underline, Font color: Auto

Formatted: No underline, Font color: Auto, English (United Kingdom)

Formatted: English (United Kingdom) 
Evgenidou, E. N., Konstantinou, I. K., \& Lambropoulou, D. A., 2015. Occurrence and removal of transformation products of PPCPs and illicit drugs in wastewaters: a review. Science of the Total Environment, 505, 905-926. doi:10.1016/j.scitotenv.2014.10.021

Fent, K., Weston, A. A., \& Caminada, D., 2006. Ecotoxicology of human pharmaceuticals. Aquatic toxicology, 76(2), 122-159. doi:10.1016/j.aquatox.2005.09.009

François, B., Armand, M., Marie-José, D., \& Thouand, G. 2016. From laboratory to environmental conditions: a new approach for chemical's biodegradability assessment. Environmental Science and Pollution Research, 23(18), 18684-18693. doi:10.1007/s11356016-7062-х

Fujii, K., \& Kikuchi, S., 2005. Degradation of benzophenone, a potential xenoestrogen, by a yeast isolated from the activated sludge of a sewage treatment plant in Hokkaido. World Journal of Microbiology and Biotechnology, 21(6-7), 1311-1315. doi:10.1007/s11274-005$2704-z_{1}$

Galinaro, C. A., Pereira, F. M., \& Vieira, E. M., 2015. Determination of parabens in surface water from Mogi Guaçu River (São Paulo, Brazil) using dispersive liquid-liquid microextraction based on low density solvent and LC-DAD. Journal of the Brazilian Chemical Society, 26(11), 2205-2213. doi:10.5935/0103-5053.20150206

Goel, M., \& Das, A. 2018. A Review on Treatment of Pharmaceuticals and Personal Care Products (PPCPs) in Water and Wastewater. Handbook of Environmental Materials Management, 1-12. doi:10.1007\%2F978-3-319-58538-3_41-1.

Gomes, J., Costa, R., Quinta-Ferreira, R. M., \& Martins, R. C. 2017. Application of ozonation for pharmaceuticals and personal care products removal from water. Science of The Total Environment, 586, 265-283. doi: 10.1016/j.scitotenv.2017.01.216

Gong, H., Klinger, J., Damazyn, K., Li, X., \& Huang, S., 2015. A novel procedure for statistical inference and verification of gene regulatory subnetwork. BMC bioinformatics, 16(7), S7. doi:10.1186/1471-2105-16-S7-S7

Gros, M., Petrović, M., \& Barceló, D., 2006. Development of a multi-residue analytical methodology based on liquid chromatography-tandem mass spectrometry (LC-MS/MS) for
Formatted: No underline, Font color: Auto, English (United Kingdom)

Formatted: English (United Kingdom)

Formatted: No underline, Font color: Auto, English (United Kingdom)

Formatted: English (United Kingdom)

Formatted: No underline, Font color: Auto, English (United Kingdom)

Formatted: English (United Kingdom)

Formatted: No underline, Font color: Auto, English (United Kingdom)

Formatted: English (United Kingdom)

Formatted: No underline, Font color: Auto, English (United Kingdom)

Formatted: English (United Kingdom)

Formatted: No underline, Font color: Auto, English (United Kingdom)

Formatted: English (United Kingdom)

Formatted: No underline, Font color: Auto, English (United Kingdom)

Formatted: No underline, Font color: Auto, Portuguese (Brazil)

Formatted: No underline, Font color: Auto

Formatted: No underline, Font color: Auto, English (United Kingdom) 
screening and trace level determination of pharmaceuticals in surface and wastewaters.

Talanta, 70(4), 678-690. doi:10.1016/j.talanta.2006.05.024

Hallé, C., 2010. Biofiltration in drinking water treatment: Reduction of membrane fouling and biodegradation of organic trace contaminants. http://hdl.handle.net/10012/5022

Haman, C., Dauchy, X., Rosin, C., \& Munoz, J. F., 2015. Occurrence, fate and behavior of parabens in aquatic environments: a review. Water research, 68, 1-11.

doi:10.1016/j.watres.2014.09.030

Heberer, T., 2002. Occurrence, fate, and removal of pharmaceutical residues in the aquatic environment: a review of recent research data. Toxicology letters, 131(1-2), 5-17. doi:10.1016/S0378-4274(02)00041-3

Henschel, K. P., Wenzel, A., Diedrich, M., \& Fliedner, A., 1997. Environmental hazard assessment of pharmaceuticals. Regulatory Toxicology and Pharmacology, 25(3), 220-225. doi:10.1006/rtph.1997.1102

Isensee, A. R., 1976. Variability of aquatic model ecosystem-derived data. International Journal of Environmental Studies, 10(1), 35-41.

Jones, O. A., Lester, J. N., \& Voulvoulis, N., 2005. Pharmaceuticals: a threat to drinking water? TRENDS in Biotechnology, 23(4), 163-167. doi:10.1016/j.tibtech.2005.02.001

Jonkers, N., Sousa, A., Galante-Oliveira, S., Barroso, C. M., Kohler, H. P. E., \& Giger, W., 2010. Occurrence and sources of selected phenolic endocrine disruptors in Ria de Aveiro, Portugal. Environmental Science and Pollution Research, 17(4), 834-843. doi:10.1007/s11356-009-0275-5

Kim, S., \& Choi, K., 2014. Occurrences, toxicities, and ecological risks of benzophenone-3, a common component of organic sunscreen products: a mini-review. Environment international, 70, 143-157. doi:10.1016/j.envint.2014.05.015.

Li, J., Zhou, Q., \& Campos, L. C., 2018. The application of GAC sandwich slow sand filtration to remove pharmaceutical and personal care products. Science of the Total Environment, 635, 1182-1190. doi:10.1016/j.scitotenv.2018.04.198
Formatted: English (United Kingdom)

Formatted: No underline, Font color: Auto, English (United Kingdom)

Formatted: English (United Kingdom)

Formatted: No underline, Font color: Auto, English (United Kingdom)

Formatted: English (United Kingdom)

Formatted: No underline, Font color: Auto, English (United Kingdom)

Formatted: English (United Kingdom)

Formatted: No underline, Font color: Auto, English (United Kingdom)

Formatted: English (United Kingdom)

Formatted: No underline, Font color: Auto, English (United Kingdom)

Formatted: English (United Kingdom)

Formatted: No underline, Font color: Auto, English (United Kingdom)

Formatted: English (United Kingdom)

Formatted: No underline, Font color: Auto, English (United Kingdom)

Formatted: English (United Kingdom)

Formatted: No underline, Font color: Auto, English (United Kingdom)

Formatted: English (United Kingdom)

Formatted: No underline, Font color: Auto, English (United Kingdom)

Formatted: English (United Kingdom) 
Lin, A. Y. C., Lin, C. A., Tung, H. H., \& Chary, N. S., 2010. Potential for biodegradation and sorption of acetaminophen, caffeine, propranolol and acebutolol in lab-scale aqueous environments. Journal of Hazardous Materials, 183(1-3), 242-250. doi:10.1016/j.jhazmat.2010.07.017

Löffler, D., \& Ternes, T. A., 2003. Determination of acidic pharmaceuticals, antibiotics and ivermectin in river sediment using liquid chromatography-tandem mass spectrometry. Journal of Chromatography A, 1021(1-2), 133-144. doi:10.1016/j.chroma.2003.08.089.

Loraine, G. A., \& Pettigrove, M. E., 2006. Seasonal variations in concentrations of pharmaceuticals and personal care products in drinking water and reclaimed wastewater in southern California. Environmental Science \& Technology, 40(3), 687-695.

doi:10.1021/es051380x

Magi, E., Scapolla, C., Di Carro, M., Rivaro, P., \& Nguyen, K. T. N., 2013. Emerging pollutants in aquatic environments: monitoring of UV filters in urban wastewater treatment plants. Analytical Methods, 5(2), 428-433. doi:10.1039/C2AY26163D

Matamoros, V., Arias, C., Brix, H., \& Bayona, J. M., 2009. Preliminary screening of small-scale domestic wastewater treatment systems for removal of pharmaceutical and personal care products. Water Research, 43(1), 55-62. doi:10.1016/j.watres.2008.10.005

Miao, X. S., Koenig, B. G., \& Metcalfe, C. D., 2002. Analysis of acidic drugs in the effluents of sewage treatment plants using liquid chromatography-electrospray ionization tandem mass spectrometry. Journal of chromatography A, 952(1-2), 139-147. doi: 10.1016/S00219673(02)00088-2

Mompelat, S., Le Bot, B., \& Thomas, O., 2009. Occurrence and fate of pharmaceutical products and by-products, from resource to drinking water. Environment international, 35(5), 803814. doi: 10.1016/j.envint.2008.10.008

Montagner, C. C., \& Jardim, W. F., 2011. Spatial and seasonal variations of pharmaceuticals and endocrine disruptors in the Atibaia River, São Paulo State (Brazil). Journal of the Brazilian Chemical Society, 22(8), 1452-1462. doi: 10.1590/S0103-50532011000800008
Formatted: No underline, Font color: Auto, English (United Kingdom)

Formatted: English (United Kingdom)

Formatted: No underline, English (United Kingdom)

Formatted: No underline, Font color: Auto, English (United Kingdom)

Formatted: English (United Kingdom)

Formatted: No underline, Font color: Auto, English (United Kingdom)

Formatted: English (United Kingdom)

Formatted: No underline, Font color: Auto, English (United Kingdom)

Formatted: English (United Kingdom)

Formatted: No underline, Font color: Auto, English (United Kingdom)

Formatted: English (United Kingdom)

Formatted: No underline, Font color: Auto, English (United Kingdom)

Formatted: English (United Kingdom)

Formatted: No underline, Font color: Auto, English (United Kingdom)

Formatted: English (United Kingdom)

Formatted: No underline, Font color: Auto, English (United Kingdom)

Formatted: English (United Kingdom) 
Nakamoto, N., 2008. Produza você mesmo uma água saborosa - sistema de purificação ecológica - revendo a tecnologia de produção de água potável. São Paulo: Ferrari. 210 p.

Oliveira, L. L.D., 2014. Biomarcadores enzimáticos e testes ecotoxicológicos na avaliação da toxicidade de fármacos em invertebrados aquáticos. Tese (Doutorado em Ciências da Engenharia Ambiental) - Universidade de São Paulo, Escola de Engenharia de São Carlos.

Onesios, K. M., Jim, T. Y., \& Bouwer, E. J., 2009. Biodegradation and removal of pharmaceuticals and personal care products in treatment systems: a review. Biodegradation, 20(4), 441-466. doi: 10.1007/s10532-008-9237-8

Parolini, M., Binelli, A., Cogni, D., Riva, C., \& Provini, A., 2009. An in vitro biomarker approach for the evaluation of the ecotoxicity of non-steroidal anti-inflammatory drugs (NSAIDs). Toxicology in vitro, 23(5), 935-942. doi: 10.1016/j.tiv.2009.04.014

Pedrouzo, M., Borrull, F., Marcé, R. M., \& Pocurull, E., 2009. Ultra-high-performance liquid chromatography-tandem mass spectrometry for determining the presence of eleven personal care products in surface and wastewaters. Journal of Chromatography A, 1216(42), 6994 7000. doi: 10.1016/j.chroma.2009.08.039

Peng, X., Yu, Y., Tang, C., Tan, J., Huang, Q., \& Wang, Z., 2008. Occurrence of steroid estrogens, endocrine-disrupting phenols, and acid pharmaceutical residues in urban riverine water of the Pearl River Delta, South China. Science of the total environment, 397(1-3), 158166. doi: 10.1016/j.scitotenv.2008.02.059

Petrović, M., Gonzalez, S., \& Barceló, D., 2003. Analysis and removal of emerging contaminants in wastewater and drinking water. TrAC Trends in Analytical Chemistry, 22(10), 685-696. doi: 10.1016/S0165-9936(03)01105-1.

Poiger, T., Buser, H. R., Balmer, M. E., Bergqvist, P. A., \& Müller, M. D., 2004. Occurrence of UV filter compounds from sunscreens in surface waters: regional mass balance in two Swiss lakes. Chemosphere, 55(7), 951-963. doi: 10.1016/j.chemosphere.2004.01.012

Pojana, G., Fantinati, A., \& Marcomini, A., 2011. Occurrence of environmentally relevant pharmaceuticals in Italian drinking water treatment plants. International journal of environmental analytical chemistry, 91(6), 537-552. doi: 10.1080/03067310903531504
Formatted: No underline, Font color: Auto, English (United Kingdom)

Formatted: No underline, Font color: Auto

Formatted: No underline, Font color: Auto, English (United Kingdom)

Formatted: English (United Kingdom)

Formatted: No underline, Font color: Auto, English (United Kingdom)

Formatted: English (United Kingdom)

Formatted: No underline, Font color: Auto, English (United Kingdom)

Formatted: English (United Kingdom)

Formatted: No underline, Font color: Auto, English (United Kingdom)

Formatted: English (United Kingdom)

Formatted: No underline, Font color: Auto, English (United Kingdom)

Formatted: English (United Kingdom)

Formatted: No underline, Font color: Auto, English (United Kingdom)

Formatted: No underline, Font color: Auto, Portuguese (Brazil)

Formatted: No underline, Font color: Auto, English (United Kingdom)

Formatted: English (United Kingdom) 
Pompei, C. M., Ciric, L., Canales, M., Karu, K., Vieira, E. M., \& Campos, L. C., 2017. Influence of PPCPs on the performance of intermittently operated slow sand filters for household water purification. Science of the Total Environment, 581, 174-185. doi: 10.1016/j.scitotenv.2016.12.091

Postigo, C., \& Richardson, S. D., 2014. Transformation of pharmaceuticals during oxidation/disinfection processes in drinking water treatment. Journal of hazardous materials, 279, 461-475. doi: 10.1016/j.jhazmat.2014.07.029

Qiao, T., Yu, Z., Zhang, X., \& Au, D. W., 2011. Occurrence and fate of pharmaceuticals and personal care products in drinking water in southern China. Journal of Environmental Monitoring, 13(11), 3097-3103. doi: 10.1039/C1EM10318K,

Ramaswamy, B. R., Shanmugam, G., Velu, G., Rengarajan, B., \& Larsson, D. J., 2011. GC-MS analysis and ecotoxicological risk assessment of triclosan, carbamazepine and parabens in Indian rivers. Journal of hazardous materials, 186(2-3), 1586-1593. doi:

10.1016/j.jhazmat.2010.12.037

Ranjard, L., Dequiedt, S., Prévost-Bouré, N. C., Thioulouse, J., Saby, N. P. A., Lelievre, M., P. A. Maron, F.E.R Morin, A. Bispo, C. Jolivet, D. Arrouays \& P. Lemanceau 2013. Turnover of soil bacterial diversity driven by wide-scale environmental heterogeneity. Nature communications, 4, 1434. doi:10.1038/ncomms2431

Renz, L., Volz, C., Michanowicz, D., Ferrar, K., Christian, C., Lenzner, D., \& El-Hefnawy, T., 2013. A study of parabens and bisphenol A in surface water and fish brain tissue from the Greater Pittsburgh Area. Ecotoxicology, 22(4), 632-641. doi:10.1007/s10646-013-1054-0.

Rigobello, E. S., Dantas, A. D. B., Di Bernardo, L., \& Vieira, E. M., 2013. Removal of diclofenac by conventional drinking water treatment processes and granular activated carbon filtration. Chemosphere, 92(2), 184-191. doi: 10.1016/j.chemosphere.2013.03.010

Rodil, R., \& Moeder, M., 2008. Development of a method for the determination of UV filters in water samples using stir bar sorptive extraction and thermal desorption-gas chromatography-mass spectrometry. Journal of Chromatography A, 1179(2), 81-88. doi: 10.1016/j.chroma.2007.11.090
Formatted: No underline, Font color: Auto, English (United Kingdom)

Formatted: English (United Kingdom)

Formatted: No underline, Font color: Auto, English (United Kingdom)

Formatted: English (United Kingdom)

Formatted: No underline, Font color: Auto, English (United Kingdom)

Formatted: English (United Kingdom)

Formatted: No underline, Font color: Auto, English (United Kingdom)

Formatted: English (United Kingdom)

Formatted: No underline, Font color: Auto, English (United Kingdom)

\section{Formatted: No underline, Font color: Auto \\ Formatted: No underline, Font color:} Auto

Formatted: No underline, Font color: Auto, English (United Kingdom)

Formatted: English (United Kingdom)

Formatted: No underline, Font color: Auto, English (United Kingdom)

Formatted: English (United Kingdom) 
Schumock, G.T., Li, E.C., Suda, K.J., Matusiak, L.M., Hunkler, R.J., Vermeulen, L.C.,

Hoffman, J.M., 2014. National trends in prescription drug expenditures and projections for 2014. American Journal of Health-System Pharmacy]->Am. J. Health Syst. Pharm. 71 (6), 482-499. doi: 10.2146/ajhp130767

Silva, C. P. D., Emídio, E. S., \& de Marchi, M. R., 2013. UV filters in water samples: experimental design on the SPE optimization followed by GC-MS/MS analysis. Journal of the Brazilian Chemical Society, 24(9), 1433-1441. doi: 10.5935/0103-5053.20130182

Sotelo, J. L., Ovejero, G., Rodríguez, A., Álvarez, S., Galán, J., \& García, J., 2014. Competitive adsorption studies of caffeine and diclofenac aqueous solutions by activated carbon.

Chemical engineering journal, 240, 443-453. doi:10.1016/j.cej.2013.11.094

Stumpf, M., Ternes, T. A., Wilken, R. D., Rodrigues, S. V., \& Baumann, W., 1999. Polar drug residues in sewage and natural waters in the state of Rio de Janeiro, Brazil. Science of the total environment, 225(1-2), 135-141. doi: 10.1016/S0048-9697(98)00339-8

Sui, Q., Cao, X., Lu, S., Zhao, W., Qiu, Z., \& Yu, G., 2015. Occurrence, sources and fate of pharmaceuticals and personal care products in the groundwater: a review. Emerging Contaminants, 1(1), 14-24. doi: 10.1016/j.emcon.2015.07.001

Tayo, L. L., Caparanga, A. R., Doma, B. T., \& Liao, C. H. (2018). A review on the removal of pharmaceutical and personal care products (PPCPs) using advanced oxidation processes. Journal of Advanced Oxidation Technologies, 21(1), 196-214. doi:10.26802/jaots.2017.0079 Ternes, T.A., 1998. Occurrence of drugs in German sewage treatment plants and rivers. Water Research. 32, 3245-3260.doi::10.1016/S0043-1354(98)00099-2

Ternes, T.; Hirsch, R.; Mueller, J.; Haberer, K., 1998. Methods for the determination of neutral drugs as well as betablockers and alpha2-sympathomimetics in aqueous matrices using GC/MS and LC/MS/MS. Fresen Journalof Analytical Chemistry. v. 362, p. 329-40. doi: $10.1007 / \mathrm{s} 002160051083$

Thomas, P. M., \& Foster, G. D., 2004. Determination of Nonsteroidal Anti-inflammatory Drugs, Caffeine, and Triclosan in Wastewaterby Gas Chromatography-Mass Spectrometry.
Formatted: Portuguese (Brazil)

Formatted: No underline, Font color: Auto, English (United Kingdom)

Formatted: English (United Kingdom)

Formatted: No underline, Font color: Auto, English (United Kingdom)

Formatted: English (United Kingdom)

Formatted: No underline, Font color: Auto, English (United Kingdom)

Formatted: English (United Kingdom)

Formatted: No underline, Font color: Auto, English (United Kingdom)

Formatted: English (United Kingdom)

Formatted: No underline, Font color: Auto, English (United Kingdom)

Formatted: English (United Kingdom)

Formatted: No underline, Font color: Auto, English (United Kingdom)

Formatted: English (United Kingdom)

Formatted: No underline, Font color: Auto, English (United Kingdom)

Formatted: English (United Kingdom)

Formatted: No underline, Font color: Auto, English (United Kingdom) 
Journal of Environmental Science and Health, Part A, 39(8), 1969-1978. doi: 10.1081/ESE120039368

Van Doorslaer, X., Dewulf, J., Van Langenhove, H., \& Demeestere, K., 2014. Fluoroquinolone antibiotics: an emerging class of environmental micropollutants. Science of the Total Environment, 500, 250-269. doi: 10.1016/j.scitotenv.2014.08.075

Verlicchi, P., Zambello, E., \& Al Aukidy, M. 2014. Removal of personal care products in constructed wetlands. In: Personal Care Products in the Aquatic Environment. Springer, Cham, 319-353. doi: 10.1007/698_2014_282

Vieno, N. M., Härkki, H., Tuhkanen, T., \& Kronberg, L., 2007. Occurrence of pharmaceuticals in river water and their elimination in a pilot-scale drinking water treatment plant. Environmental science \& technology, 41(14), 5077-5084. doi:10.1021/es062720x

Westerhoff, P., 2003. Removal of endocrine disruptors, pharmaceuticals, and personal care products during water treatment. Southwest hydrology, 2(6), 18-19.

Wiesenberg-Boettcher, I., Pfeilschifter, J., Schweizer, A., Sallmann, A., \& Wenk, P., 1991. Pharmacological properties of five diclofenac metabolites identified in human plasma. Agents and actions, 34(1-2), 135-137. doi:10.1007/BF01993259

Winkler, M., Lawrence, J. R., \& Neu, T. R., 2001. Selective degradation of ibuprofen and clofibric acid in two model river biofilm systems. Water Research, 35(13), 3197-3205. doi:10.1016/S0043-1354(01)00026-4

Xu, Y., Liu, T., Zhang, Y., Ge, F., Steel, R. M., \& Sun, L. 2017. Advances in technologies for pharmaceuticals and personal care products removal. Journal of Materials Chemistry A, 5(24), 12001-12014. doi:10.1039/C7TA03698A
Formatted: English (United Kingdom)

Formatted: No underline, Font color: Auto, English (United Kingdom)

Formatted: English (United Kingdom)

Formatted: No underline, Font color: Auto, English (United Kingdom)

Formatted: English (United Kingdom)

Formatted: No underline, English (United Kingdom)

Formatted: No underline, Font color: Auto, English (United Kingdom)

Formatted: No underline, English (United Kingdom)

Formatted: English (United Kingdom) Formatted: No underline, English (United Kingdom)

Formatted: English (United Kingdom)

Formatted: No underline, Font color: Auto, English (United Kingdom)

Formatted: English (United Kingdom)

Formatted: No underline, Font color: Auto, English (United Kingdom)

Formatted: English (United Kingdom)

Formatted: No underline, Font color: Auto, English (United Kingdom)

Formatted: English (United Kingdom) 
1 Occurrence of PPCPs in a Brazilian Water Reservoir and their Removal Efficiency

2

3 Caroline Moço Erba Pompei ${ }^{*}$; Luiza Cintra Campos ${ }^{2 * *}$; Bianca Ferreira da Silva ${ }^{3}$; José

\section{by Ecological Filtration.}

1. Water Resources and Applied Ecology Center, São Carlos School of Engineering, University of São Paulo, São Carlos, SP, Brazil. E-mail: caroline_erba@yahoo.com.br

2. Department of Civil, Environmental and Geomatic Engineering, University College London, Gower Street, London WC1E 6BT, United Kingdom. E-mail: 1.campos@ucl.ac.uk

3. Institute of Chemistry - State University “Julio de Mesquita Filho"-UNESPAraraquara, SP, Brazil. E-mail: biribisfs@gmail.com

4. Department of Statistics, Federal University of São Carlos, SP, Brazil. E-mail: fogo@ufscar.br

5. Department of Chemistry and Molecular Physics, São Carlos Institute of Chemistry, University of São Paulo, São Carlos, SP, Brazil. E-mail: eny@iqsc.usp.br

\section{*Corresponding author}

**Corresponding author

E-mails: *caroline_erba@yahoo.com.br; **1.campos@ucl.ac.uk

Postal addresses: *Avenida Trabalhador São Carlense, 400, Caixa Postal 292, São Carlos, SP, CEP 13560-970. **Department of Civil, Environmental and Geomatic Engineering, University College London, Chadwick Building, Room GM11, Gower Street, London WC1E 6BT, United Kingdom 


\section{Abstract}

The presence of PPCPs (Pharmaceuticals and Personal Care Products) in water sources and drinking water has concerned researchers in recent times. This study was carried out to evaluate the occurrence of 6 PPCPs (namely paracetamol, diclofenac, naproxen, ibuprofen, benzophenone-3 and methylparaben) in the Lobo reservoir, their degradation products, and how efficienctly they were removed by 22 ecological filters, considering individual and mixtures of compounds. There were 3 spiking events of PPCPs $\left(2 \mu \mathrm{g} \mathrm{L}^{-1}\right)$ in the ecological filter influents conducted with a lag period of 15 days between spikes. Water sample were collected from the influent and effluent of the filters at 3, 6 and 24 hours after each spiking event. All target PPCPs were identified in the Lobo reservoir water in the range of $\mu \mathrm{g} \mathrm{L}^{-1}$. The personal care products were detected with $100 \%$ frequency in the samples, and in higher concentrations compared to the pharmaceuticals. Degradation products of diclofenac and benzophenone-3 were identified in the water samples. Results of this investigation show that an ecological filter was an effective process $(70-99 \%)$ to remove $2 \mu \mathrm{g} \mathrm{L}{ }^{-1}$ of the selected PPCPs, and demonstrated that the filters were resilient to individual compounds and to their mixtures.

Keywords: Ecological filtration; drinking water treatment; removal of PPCPs; degradation products. 


\section{Introduction}

Pharmaceuticals and Personal Care Products (PPCPs) are of scientific and public concern as newly recognized classes of environmental pollutants; described as emerging water contaminants with potential psychoactive properties and unknown effects to the aquatic environment (Evgenidou et al., 2015). The term "PPCPs" refers to any chemical product with healthcare or medical purposes for humans and/or animals (Schumock et al. 2014).

The most consumed non-steroidal anti-inflammatory drugs frequently found in aquatic environments are aspirin, acetaminophen, ibuprofen, naproxen and diclofenac (Fent et al., 2006). These PPCPs and others have been detected worldwide in surface water, groundwater, sewage and even drinking water in the order of $n g-\mu g \mathrm{~L}^{-1}$ (Heberer, 2002; Petrović et al., 2003; Fent et al., 2006; Ellis, 2006; Sui et al., 2015). Additionally, degradation products (DPs) of these PPCPs have been found in water bodies and water samples after treatment as a result of a multiplicity of biotic and abiotic processes (e.g. hydrolysis, photolysis, oxidation, and microbiological metabolism) acting on the original compounds or their metabolites (Mompelat et al., 2009; Dévier et al., 2011; Andrés-Costa et al., 2014; Van Doorslaer et al., 2014; Postigo and Richardson, 2014). PPCP removal has been observed in wastewater treatment plants (WWTPs) (e.g. Ternes et al., 1998; Thomas and Foster, 2004, Camacho-Munoz et al., 2012). However, in general, most of WWTPs are not designed to treat this type of substance, and consequently a significant portion of these compounds are not degraded/removed during treatment. Therefore, the pure compound and/or their metabolites may enter the aquatic environment via sewage effuents (Daughton and Ternes, 1999; Heberer, 2002; Petrović et al., 2003; Jones et al., 2005; Fent et al., 2006; Matamoros et al., 2009). Furthermore, conventional drinking water treatment processes have been reported as ineffective for 
the removal of most pharmaceuticals, with efficiency ranging from $<5$ to $40 \%$ (Vieno et al., 2007; Pojana et al., 2011).

Recently, numerous investigations have been carried out using advanced oxidation processes (AOPs) such as ozonation, UV oxidation, fenton and fenton-like processes, and photocatalytic degradation to remove PPCPs from water and wastewater (Tayo et al., 2018; Goel and Das, 2018; Xu et al., 2017). However, the relatively high cost of these processes currently stand as the major barrier for their large-scale implementation (Xu et al., 2017), especially in developing countries such as Brazil. Conversely, there is evidence of PPCP removal by sandfiltration, in which biodegradation has been suggested as one of the removal mechanisms (Westerhoff, 2003; Fujii and Kikuchi, 2005; Hallé, 2010; Onesios et al., 2009; Camacho-Munoz et al. 2012; Chen et al., 2015; Chen et al., 2016). For example, Qiao et al. (2011) investigated the occurrence of 15 PPCPs in two full-scale conventional treatment plants; they found that the type and concentration of PPCP decreased gradually along the treatment train, especially after sand filtration. Beretelkamp et al. (2014), simulated the removal of 14 organic compounds by river bank filtration at a laboratory scale; they obtained a statistically significant relationship between the biological degradation rates and the compound functional groups. In addition, removal of PPCPs has been observed in slow sand filtration (SSF) and granular activated carbon (GAC) sandwich SSF (Erba et al., 2014; Escolà Casas and Bester, 2015; Pompei et al., 2017; Li et al., 2018). Therefore, biosandfiltration seems an attractive option due to its demonstrated potential of removing PPCPs from water and its low operational cost for not requiring chemical coagulation. Slow sand filtration has been recently referred to as ecological filtration due to the presence of a biofilm that forms on top of the sand filter and is believed to be essential to water purification (Nakamoto, 2008). 
in a Brazilian water reservoir, and their removal by ecological filters installed under natural environmental conditions, receiving water from the Lobo reservoir in Itirapina,

São Paulo state. To the best of the authors' knowledge, this is the first study investigating the removal of individual target compounds, their mixture, and their degradation products by ecological filtration at a pilot scale.

\section{Material and methods}

\subsection{Chemicals and Reagents}

Acetonitrile $\left(\mathrm{CH}_{3} \mathrm{CN}\right)$ and methanol $\left(\mathrm{CH}_{3} \mathrm{OH}\right)$ were of HPLC grade from J.T. Baker (Xalostoc, México), Formic acid, 4-Acetaminophen (ACT), Diclofenac sodium salt (DCF), Naproxen (NAP), Ibuprofen (IBU), Metyl 4-hydroxybenzoate (MEP) and 2Hydroxy-4-methoxybenzophenone (BP-3) (all $99 \%$ purity or more) were purchased from Sigma-Aldrich. The deuterated compounds were used as internal standards, namely paracetamol- $d 4$, diclofenac- $d 4$, naproxen- $d 3$, ibuprofen- $d 3$; all obtained from CDN Isotopes (Quebec, Canada). Additional information about each compound is shown in Table S1. Stock solutions were prepared in methanol for each compound and stored in a refrigerator at $4{ }^{\circ} \mathrm{C}$. For all reagent solutions, water was previously distilled and further deionized using a Milli-Q system Millipore (Millipore, Bedford, MA, USA).

\subsection{Filter construction}

Twenty-two ecological filters (Nakamoto, 2008) were constructed with PVC columns (Figure S1). Each ecological filter had an internal diameter of $25 \mathrm{~cm}$ and height of $72 \mathrm{~cm}$. The support layer in each filter was formed by a $15 \mathrm{~cm}$ gravel layer, with 3 sub-layers of $12.50 \mathrm{~mm}$ to $1.41 \mathrm{~mm}$. The sand layer had $30 \mathrm{~cm}$ height with grain 
123 sizes varying from 1.00 to $0.08 \mathrm{~mm}$. The sand uniformity coefficient was between 2 and

124 3, and the effective grain size was $0.25 \mathrm{~mm}$ (Bellamy et al., 1985; Di Bernardo, 1993).

125 The water layer on the top of the sand bed varied from 25 to $27 \mathrm{~cm}$. The influent water

126 to the 22 ecological filters was pumped from the Lobo reservoir $\left(22^{\circ} 10^{\prime} 18.09 " \mathrm{~S}\right.$

$1274^{\circ} 54^{\prime} 5.00^{\prime \prime}$ ), located at Itirapina city, São Paulo, Brazil, to a constant level tank

128 before being supplied continuously to the filters.

\subsection{Water Sampling}

The operation of filters was continuous and the average water filtration flow rate was $3 \mathrm{~m}^{3} / \mathrm{d} \cdot \mathrm{m}^{2}$. There was triplicate of 6 filters with each individually receiving a PPCP compound (18 filters), triplicate of 1 filter receiving a mixture of the 6 PPCP compounds (3 filters), and 1 control filter receiving only water from the Lobo reservoir (Table S2).

After maturation of the filters, three spiking events of the target PPCPs were conducted with a lag period of 15 days between spikes. The spikes were created to certify that a known concentration would enter the ecological filters, as the main concentration of PPCPs on the reservoir water may vary and may not be detected every day. The spike solution (1L) was added to the raw water inlet via a dosing pump. Samples of the reservoir water were collected at the same time as the filter effluent water (3, 6, and 24 hours after spikes) to determine the background concentration of the target PPCPs. The point of water sample collection in the reservoir was always the same, at the location of the hydraulic pump used to supply the 22 filters $\left(22^{\circ} 10^{\prime} 18.09 " \mathrm{~S}\right.$ $\left.47^{\circ} 54^{\prime} 5.00 " \mathrm{~W}\right)$.

For PPCP detection, water samples $(500 \mathrm{~mL})$ were collected in each contaminated filter after every contamination event (total per filter $=3$ samples 
(triplicate) x 3 spike events $=9$ samples; total $=189$ samples $)$, while in the control filter only 9 samples were collected in total. To evaluate the removal efficiency of each filter, the total initial concentration of each target PPCP compound was considered as the sum of the background concentration found in the reservoir water, plus the spiked PPCP

152 concentration of $2 \mu \mathrm{g} \mathrm{L}^{-1}$. For physico-chemical and bacteriological analyses, samples of $500 \mathrm{~mL}$ were collected weekly from the influent and effluent of each filter during the

154 first month of operation; they were also collected from $9^{\text {th }}$ October in 2013 , when the filters were considered matured, water samples were collected 3 times per week (samples in each filter $=30$; total samples $=660$ samples $)$. measured from September to December 2013. Turbidity and apparent colour were determined by a HACH DR 2000 espectrofotometer, selecting $\mathrm{UV}_{455 \mathrm{~nm}}$ for colour and spiking the PPCPs into the ecological filters.

\subsection{PPCPs and DPs detection}


The PPCPs were extracted from the water samples using solid phase extraction

173 (SPE) with Strata-X (Phenomenex) Polymeric Reversed Phase 200 mg/6 mL (8B-S100-

$174 \mathrm{FCH}$ ). Each cartridge was pre-conditioned with $6 \mathrm{~mL}$ of methanol (2 times), $6 \mathrm{~mL}$ of purified water (Milli-Q), and $6 \mathrm{~mL}$ of purified water (Milli-Q) acidified with $\mathrm{HCl}$ for pH 3 per gravity. After, $300 \mathrm{~mL}$ of water $(\mathrm{pH} 3.0)$ was passed through the cartridge

177 sorbent at a flow rate of $5 \mathrm{~mL} \mathrm{~min}^{-1}$. The PPCPs were eluted passing $4 \mathrm{~mL}$ of methanol 178 twice, and the volume was reduced with a gentle stream of nitrogen gas and reconstituted to $300 \mu \mathrm{L}$ with $\mathrm{MeOH}+\mathrm{Milli}-\mathrm{Q}$ water $(1: 1 \mathrm{v} / \mathrm{v})$. The samples were then analyzed by LC-MS/MS. Additional information about the LC-MS/MS equipment, method used and how analyses were conducted for the identification of DPs are described in the Supporting Information. Quality assurance and quality control (QA/QC) were implemented for the accuracy of the quantification of the target PPCPs. More details are also presented in the Supporting Information and Tables S3 and S4. ecological filters, the standard deviation (SD) and coefficient of variation (CV) were 
(Isensee, 1976). In addition, t-tests were done to examine the relationships between influent and effluent water from ecological filters; values were significant at $p<0.05$. The averages, SDs, CVs and t-tests of data were calculated using Microsoft Excel 2010.

\section{Results and discussion}

\subsection{LC-MS/MS}

The adjustment of parameters for each compound and deuterates of the mass spectrometer to the individual samples of all compounds are shown in Table S5. The transition ions, or ion fragments selected in this study are in agreement with fragment ions for the same compounds described elsewhere (Miao et al., 2002; Löffler and Ternes, 2003; Rodil and Moeder, 2008; Magi et al., 2013) (Figure S2).

\subsection{Water quality parameters}

The mean values of each water quality parameters are shown in Figure S3 and Table S6. The ecological filters met the quality parameters except that for coliform counts, set by the Ordinance No. 2914/2011 which defines the standards of water potability in Brazil (Brasil, 2011). However, the filters had a high percentage of removal of coliforms (Figure S4) as the raw water was diluted 500 times to be count, and in the effluent of filters no dilutions were made. The filters were considered mature from $9^{\text {th }}$ October $( \pm 1$ month of maturation). In addition, total coliforms and E. coli were observed to have low variability among the 22 ecological filters, as SD and CV were lower than 20-30\% (Isensee, 1976) in each water sample collected during the sampling period (Table S7); this demonstrated the stability and robustness of the ecological 
221 filtration system. Thus, the removal of bacteria was not affected by the presence of 222 PPCPs.

223

\subsection{Occurrence of PPCPs in the Lobo reservoir water}

The 6 target PPCPs were identified and quantified in the Lobo reservoir water, which supplied the 22 ecological filters from September to December of 2013. The concentration of each compound detected in the filter influent water are shown in Table 1. It shows that all pharmaceuticals (i.e. ACT, DCF, NAP, and IBU) were not found, at least in one sampling day in the Lobo reservoir water. In contrast, personal care products (i.e. MEP and BP-3) were found with $100 \%$ frequency, and in high concentrations compared to the pharmaceutical compounds.

Table 1: Concentrations of the compounds detected by SPE-LC-MS/MS in water samples from the Lobo reservoir.

\begin{tabular}{l|c|c|c|c}
\hline \multicolumn{5}{c}{ Raw water } \\
\hline PPCPs & $\begin{array}{c}\text { Min. Conc. } \\
\left(\mu \mathrm{g} \mathrm{L}^{-1}\right)\end{array}$ & $\begin{array}{c}\text { Max. Conc. } \\
\left(\mu \mathrm{g} \mathrm{L}^{-1}\right)\end{array}$ & $\begin{array}{c}\text { Mean Conc. } \\
\left(\mu \mathrm{g} \mathrm{L}^{-1}\right)\end{array}$ & $\begin{array}{c}\text { Frequency } \\
\text { detected }(\%)\end{array}$ \\
\hline ACT & n.d. & 0.13 & 0.03 & 85.70 \\
DCF & n.d. & 0.05 & 0.02 & 71.40 \\
NAP & n.d. & 0.10 & 0.01 & 85.70 \\
IBU & n.d. & 0.13 & 0.01 & 42.80 \\
MEP & 0.10 & 1192.39 & 170.87 & 100.00 \\
BP-3 & 0.32 & 2.10 & 1.14 & 100.00 \\
\hline n.d.: not detected.
\end{tabular}
n.d.: not detected 
respectively). Similarly, investigation work done in the state of São Paulo, Brazil, found MEP at several points of the river Mogi Guaçu at which the water had on average concentrations of $8 \mu \mathrm{g} \mathrm{L}^{-1}$, where $27.50 \mu \mathrm{g} \mathrm{L}^{-1}$ was the highest concentration (Galinaro et al., 2015). In our study, the average concentration of MEP detected in the Lobo reservoir water was $170.87 \mu \mathrm{g} \mathrm{L}^{-1}$, which is much higher than the spiked concentration of $2 \mu \mathrm{g} \mathrm{L^{-1 }}$.

If neglecting atypical days, the average concentration detected of MEP was 0.62 $\mu \mathrm{g} \mathrm{L} \mathrm{L}^{-1}$, which is similar to concentrations found from 0.005 to $79.60 \mu \mathrm{g} \mathrm{L}^{-1}$ in several water bodies worldwide e.g. India, USA, UK, China and several European countries (Benijts et al., 2004; Loraine and Pettigrove, 2006; Peng et al., 2008; Blanco et al., 2009; Pedrouzo et al., 2009; Jonkers et al., 2010; Ramaswamy et al., 2011; Renz et al., 2013; Haman et al., 2015). However, the average concentration of BP-3 in the Lobo reservoir water was $1.14 \mu \mathrm{g} \mathrm{L}^{-1}$, higher than the other published work. For example, in lakes in Switzerland the concentration of BP-3 was found to range from $<2$ to $125 \mathrm{ng} \mathrm{L}^{-}$ ${ }^{1}$ (Poiger et al., 2004). In Brazil, Silva et al. (2013) reported $<2 \mathrm{ng} \mathrm{L}^{-1}$ in Araraquara city, São Paulo. It has also been found in several countries such as Japan, Spain, South Korea, United Kingdom etc. at concentrations from $<0.30$ to $103 \mathrm{ng} \mathrm{L}^{-1}$ (Kim and Choi, 2014).

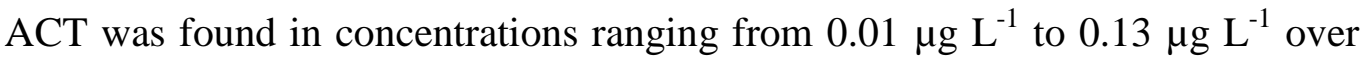
the study period, with an average concentration of $0.04 \mu \mathrm{g} \mathrm{L}^{-1}$. In other studies conducted in Brazil, Almeida and Weber (2009) reported ACT concentrations in Billings dam between 0.30 and $10.30 \mathrm{ng} \mathrm{L}^{-1}$. Montagner and Jardim (2011) found 13.44 ng $\mathrm{L}^{-1}$ in water samples from the basin of Atibaia, and Oliveira (2014) reported the concentration 11-531 $\mathrm{ng} \mathrm{L}^{-1}$ in the Guarapiranga dam. In other countries ACT was found with a mean concentration of $0.05 \mu \mathrm{g} \mathrm{L} \mathrm{L}^{-1}$ (Bound and Voulvolis, 2006; Gros et 
al., 2006). ACT is one of the most frequently found drugs in surface water, wastewater and drinking water (Parolini et al., 2009). Henschel et al. (1997) classified this compound as harmful to aquatic organisms, based on some ecotoxicological tests with different biological models such as bacteria, algae, cladocerans and fish.

DCF is among the 10 compounds most often found in aquatic ecosystems (Sotelo et al., 2014). In our work its average detected concentration was $0.02 \mu \mathrm{g} \mathrm{L}^{-1}$, and it was not found or was below the detection limit in 3 of the 9 samples taken. In Brazil, DCF was also found in the Billings dam in concentrations from 8.10 to 394.50 ng $\mathrm{L}^{-1}$ (Almeida and Weber, 2009), the concentration in the Guarapiranga dam was between 6 to $36 \mathrm{ng} \mathrm{L}^{-1}$ (Oliveira, 2014), and in Rio de Janeiro it was found at a concentration of $60 \mathrm{ng} \mathrm{L}^{-1}$ (Stumpf et al., 1999). In Germany, the concentration reached $600 \mathrm{ng} \mathrm{L}^{-1}$ (Heberer, 2002). In addition, NAP and IBU, are also amongst the most frequent drugs found in water bodies, and were found with an average concentration of $0.03 \mu \mathrm{g} \mathrm{L^{-1 }}$ and $0.06 \mu \mathrm{g} \mathrm{L}^{-1}$, respectively. However, the results agree with other Brazilian studies that found these compounds in the Billings dam (10 to $78.20 \mathrm{ng} \mathrm{L}^{-1}$ ) (Almeida and Weber, 2009), and Rio de Janeiro $\left(<0.01 \mu \mathrm{g} \mathrm{L}^{-1}\right)$ (Stumpf et al., 1999). In our study NAP was not found in one of the sampling days, and was below the limit of quantification in three of the sampling days. Also, IBU was not found in four of the sampling days, and was below the limit of quantification in one of them.

According to meteorological data collected at the climatological station of the Centre for Water Resources and Environmental Studies (CRHEA in Portuguese), which follows the rules of the World Meteorological Organization, on the day of the first collection it rained an average of $55.40 \mathrm{~mm}$. However, the reservoir has several houses in its surroundings and high recreational and tourist activities, a fact that has been described previously (Calijuri and Tundisi, 1990) to have resulted in environmental 
changes by human activities such as deforestation, dumping of domestic sewage and

290

291

292

293

294

295

296

297

298

299

300

301

302

303

304

305

306

307

308

309

310

311

312

fertilizers used in some agriculture areas. The first water sampling took place on 11.04.2013 (Monday), and interestingly, on the previous weekend there was a national bank holiday. Therefore, there was a likely increase in the use of the reservoir for bathing, and its surroundings for recreational activities. This combined with the potential wastewater discharge by the ranches that border the reservoir might have contributed to the increase in the concentration of the target compounds such as DCF $\left(0.05 \mu \mathrm{g} \mathrm{L}^{-1}\right), \mathrm{NAP}\left(0.10 \mu \mathrm{g} \mathrm{L}^{-1}\right), \mathrm{IBU}\left(0.13 \mu \mathrm{g} \mathrm{L} \mathrm{L}^{-1}\right)$, and especially MEP $(1192.39 \mu \mathrm{g}$ $\left.\mathrm{L}^{-1}\right)$.

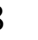

\subsection{Degradation Products}

The DP extractions were performed for each mass found for all DPs of each PPCP compound, and those that were detected in the samples were selected for fragmentation analysis. The selected masses were: $\mathrm{m} / z, 292$ and $\mathrm{m} / \mathrm{z} 278$ (DP of DCF), $m / z 201$ (DP of MEP), $m / z 282$ (DP of DCF), $m / z 185$ (DP of MEP), $m / z 245$ and $\mathrm{m} / \mathrm{z}$ 215 (DP of BP-3), $m / z 231$ (DP of BP-3), based on the literature described in Section 1.1 of the Supporting Information. The ion scanning experiments for the samples were carried out, and through analysing the spectra it was observed that the same compounds detected in the reservoir water samples, at all times and days of sampling, were the same found in the filter effluent samples. This suggests the same compounds, which were expected to be identified as DPs generated by the treatment during ecological filtration, were already present in the incoming water (Lobo reservoir). This is confirmed by the presence of the background concentration of each target compound in the reservoir water (Table 1). 
314 found in all samples and further analysed. The DP $291(\mathrm{~m} / z$ 292) showed fragments ion $274\left(\mathrm{C}_{14} \mathrm{H}_{9} \mathrm{NO}_{3} \mathrm{Cl}\right), 218\left(\mathrm{C}_{12} \mathrm{H}_{9} \mathrm{NOCl}\right)$ and $150\left(\mathrm{C}_{11} \mathrm{H}_{4} \mathrm{~N}\right)$ (Figure 1a). The DP $244(\mathrm{~m} / \mathrm{z}$

$316245)$ was presented as the principal fragments $217\left(\mathrm{C}_{13} \mathrm{H}_{13} \mathrm{O} 3\right), 199\left(\mathrm{C}_{13} \mathrm{H}_{11} \mathrm{O}_{2}\right), 189$

$317\left(\mathrm{C}_{12} \mathrm{H}_{13} \mathrm{O}_{2}\right)$ and $157\left(\mathrm{C}_{11} \mathrm{H}_{9} \mathrm{O}\right)$ (Figure $\left.1 \mathrm{~b}\right)$. Both compounds are consistent with the 318 literature (e.g. Wiesenberg-Boettcher et al, 1991; Agüera et al., 2005; Gong et al., 319 2015), and have been detected in water bodies. It is worth noting that the DPs were only 320 identified but not quantified by the method, as there was no sufficient sensitivity at trace 321 levels. Therefore, further research on quantification of the DP compounds in the water 322 reservoir and the effluent of the ecological filters is recommended.

(a) +MS2 (292.00) CE (25): $\operatorname{Exp} 6,4.331$ to $6.393 \mathrm{~min}$ from ... Max. $3288.2 \mathrm{cps}$.

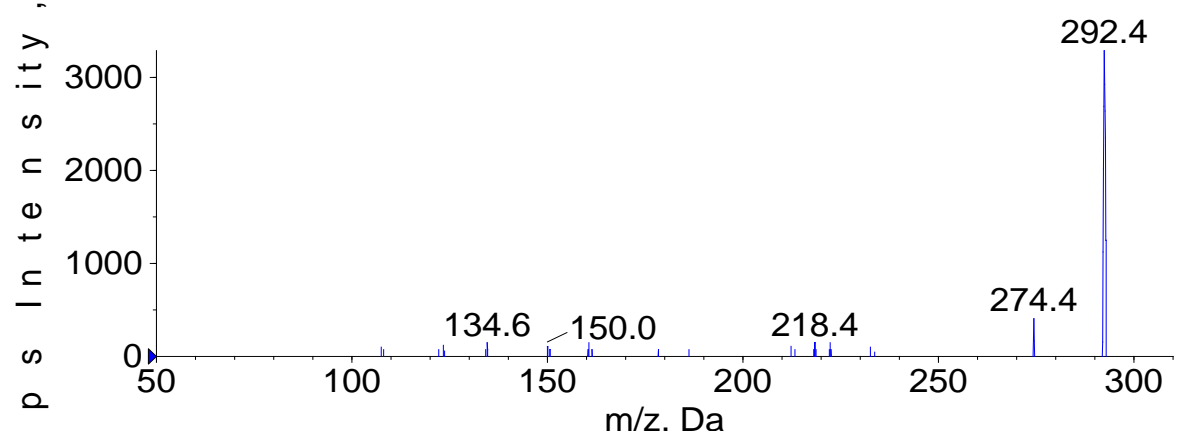


<smiles>O=C1C=CC(=Nc2c(O)cccc2Cl)C(CC(=O)O)=C1</smiles>

$\mathrm{m} / \mathrm{z} 292$<smiles>c1ccc2c3ccc4c(nc2c#1)-[c+]=c-4-3</smiles>

$\mathrm{m} / \mathrm{z} 150$<smiles>O=[C-]CC1=CC(=O)C=CC1=Nc1c(O)cccc1Cl</smiles>

$m / z 274$

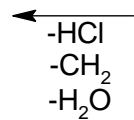

$-\mathrm{H}_{2} \mathrm{O}$

330

331

b)

【+MS̄2 (245.00) CE (25): Exp 12, 4.640 to 5.550 min fro...

3742

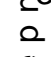$$
\text { i }
$$

332

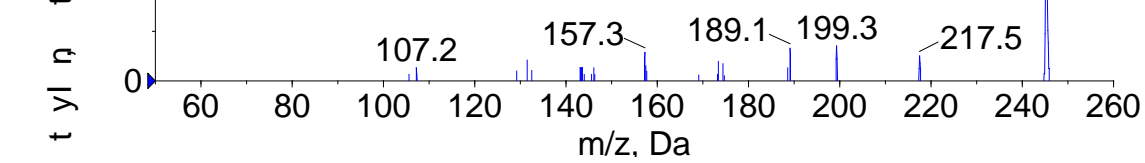

\section{3}

$m / z 218$<smiles>[CH2+]C1=CC=CC1=Nc1c(O)cccc1Cl</smiles><smiles>[3H]C(C)=O</smiles>

$m / z 246$ 
<smiles>COc1ccc(C(=O)c2cccc(O)c2)c(O)c1</smiles><smiles>CC(C)(C)CC1CCCCC1</smiles><smiles>COc1ccc(-c2ccccc2O)c(C)c1</smiles><smiles>COc1ccc(-c2cccc(O)c2)cc1</smiles>

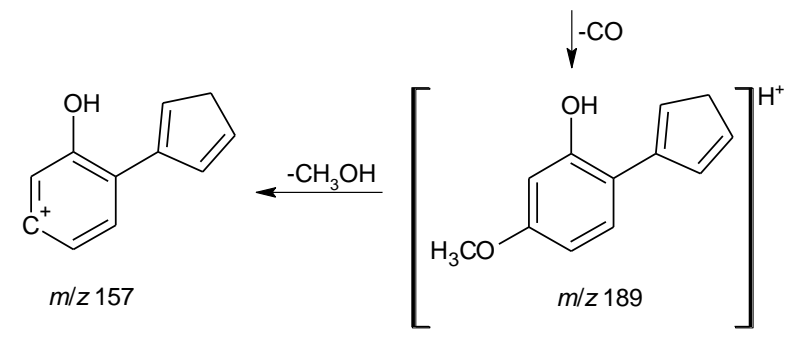

Figure 1: Identified fragment ions spectra of the degradation products (DPs), and proposed fragmentation mechanism for both water reservoir and effluent of the ecological filters: a) DP of DCF; b) DP of BP-3.

\subsection{Removal of PPCPs by the ecological filters}

The mean removal efficiencies of the selected PPCPs are discussed below by class of compounds i.e. pharmaceuticals (Figures 2 and 3) and personal care products receiving individual compound (FEco), control filter (Control) and three filters receiving the mix solution (Mix).

\subsubsection{Removal of pharmaceuticals}

\section{Analgesic (ACT)}

The efficiency of ecological filters to remove ACT in this study was on average 
system. For example, Erba et al. (2012) reported $80 \%$ removal of $2 \mu \mathrm{g} \mathrm{L}{ }^{-1}$ of ACT by an ecological filter. On the other hand, Li et al. (2018) reported removals above 78-67 $\%$ of $25 \mu \mathrm{g} \mathrm{L}^{-1}$ of ACT using GAC-sandwich SSF, while Pompei et al. (2017) found 65 $\%$ removal of $2 \mu \mathrm{g} \mathrm{L}^{-1}$ ACT using household SSF. Our higher removal value might have been due to the fact that the filters were located outdoors and not in laboratory as per Pompei et al. (2017) and Li et al. (2018). Although laboratory tests attempt to simulate natural conditions, these tests do not consider environmental changes such as microbial community diversity, quantity, and climatic conditions, which evolve over time and space in nature (Ranjard et al., 2013). Therefore, biological degradation processes in environmental conditions are influenced by other variables that are present in natural environments (Francois et al., 2016). Because of the variability between laboratory and environmental conditions, it is suggested to carry out research in natural conditions to produce more authentic application results.

Another reason for the difference in results could be the sand uniformity coefficient used in each filter. Erba et al. (2012) worked with a filter sand of similar uniformity coefficient (effective size $=0.25 \mathrm{~mm}$, uniformity coefficient $=2-3$ ) to ours, while Pompei et al. (2017) (effective size $=0.210 \mathrm{~mm}$, uniformity coefficient $=1.4$ ) and Li et al. (2018) (effective size of $0.6 \mathrm{~mm}$, uniformity coefficient $=1.4$ ) had smaller values for the uniformity coefficient. These confirm the findings by Di Bernardo and Rivera (1996) who found that the biological layer (i.e. schmutzdecke) was larger in filters containing sand with a larger uniformity coefficient. Therefore, it is possible that the biological layer in our work was larger than the ones in Pompei et al. (2017) and $\mathrm{Li}$ et al. (2018), leading to a larger removal of the target PPCPs. Campos et al. (2002) suggested that the schmutzdecke is responsible for significant inputs of carbon substrates to the underlying sand layer supporting interstitial microbial growth. These results 
confirm that biodegradation is a major mechanism for ACT removal (Onesios et al., 2009; Lin et al., 2010).

The ecological filters were less efficient than AOP systems such as fenton, UV and ozone oxidations which were shown to remove $100 \%$ of ACT when using synthetic water (Tayo et al., 2018). However, the high cost of these technologies and the use of chemicals during the treatment make them unattractive when compared to ecological filters which have presented very good levels of ACT removal. Finally, the statistical analysis MANOVA showed no significant difference $(p>0.05)$ between the type of filter (Control, FEco or Mix) and collection times (3, 6 and 24 hours), although the Control filter had a lower percentage of removal compared to the FEco and Mix filters (Figure 2). The error bars were higher in the Control filter, because there were no triplicates of this filter, but only for FEco and Mix filters (Figure 2).

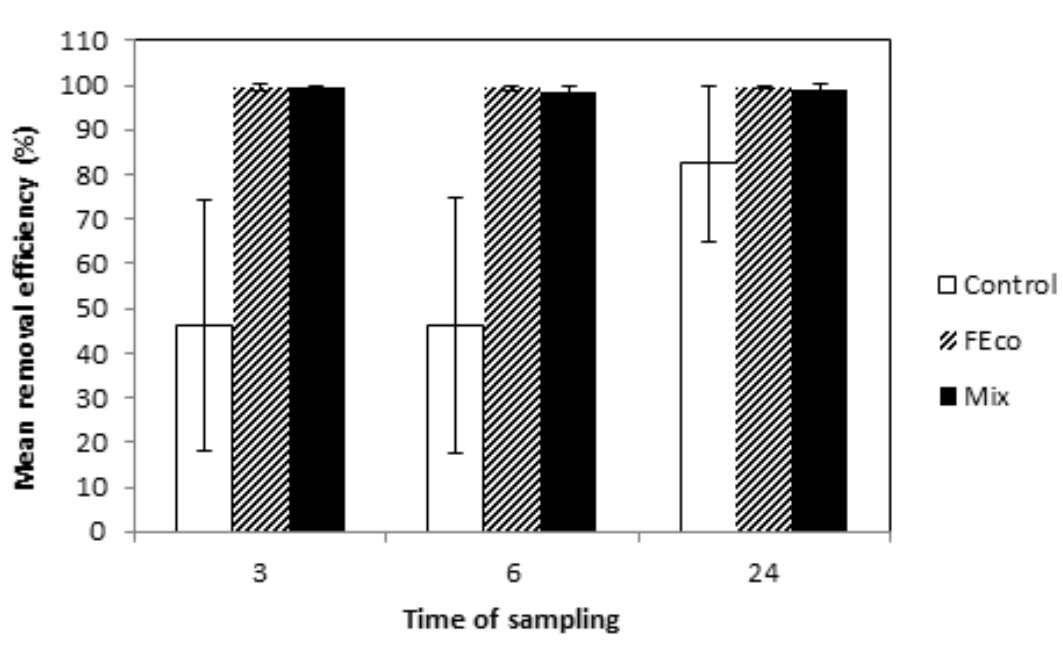

Figure 2: Mean removal (\%) of ACT by ecological filtration, in Control filter $(\mathrm{n}=9)$, FEco $(n=27)$ and Mix $(n=27)$.

\section{Anti-inflammatory (DCF, IBU, NAP)}



previous findings of $94 \%$ DCF removal by ecological filters elsewhere (Erba et al.,

400

401

402

403

404

405

406

407

408

409

410

411

412

413

414

415

416

417
2012). On the other hand, Rigobello et al. (2013) found that there was no removal of

DCF by conventional SSF, however, their experiment was conducted using synthetic water. Therefore, it is possible that there was no ideal formation of the biofilm which is easily formed using natural water from lakes and/or rivers, where there is already an aquatic biota that can colonize the top of the filter sand. Also, DCF removal by WWTPs showed large differences in removal, e.g. $17 \%$ (Heberer, 2002), $69 \%$ (Ternes, 1998), and $100 \%$ (Thomas and Foster, 2004), this may be due to differences in temperature and climate (Delpla et al., 2009). When comparing this to advanced treatment, the ecological filters provided similar DCF removal (91\%) to AOPs applying ozonation and UV oxidation (100\%), and fenton oxidation (> $85 \%$ ) (Tayo et al., 2018). The results again demonstrate the benefit of using ecological filtration without the need of chemicals, and confirm that biodegradation is an important mechanism for DCF removal (Onesios et al., 2009).

For IBU the ecological filters removed on average $99 \%$ of it. This is in agreement with Erba et al. (2012) who found IBU removal of $76 \%$ by ecological filters, and Winkler et al. (2001) who evaluated the biodegradation of IBU by biofilm from surface waters and observed a rapid degradation up to $90 \%$. Yet for NAP the ecological filters removed on average $97 \%$ of it; this result also agrees with Erba et al. (2012) who found NAP removal of $87 \%$ using ecological filters. In comparison with advanced processes, our results show that the ecological filter is capable of also removing IBU and NAP with similar efficiencies to AOPs using ozonation (> $99 \%$ ), UV oxidation $(100 \%)$ and fenton oxidation (> $50 \%$ ) (Tayo et al., 2018). 
426

430 (a)

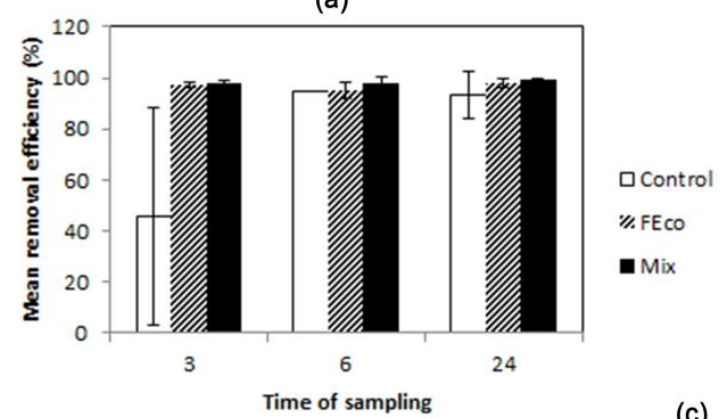

(c)

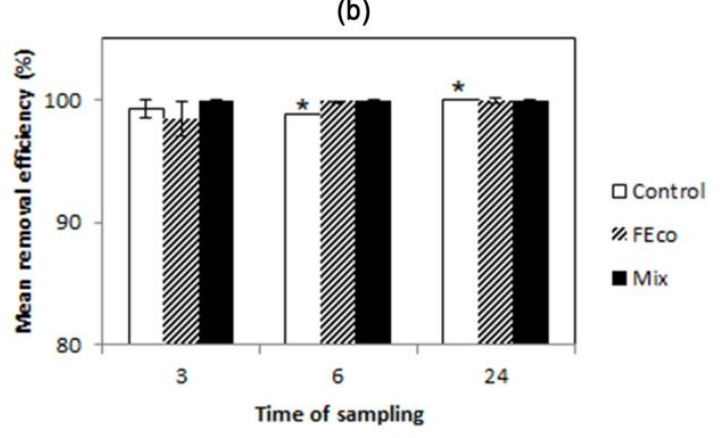

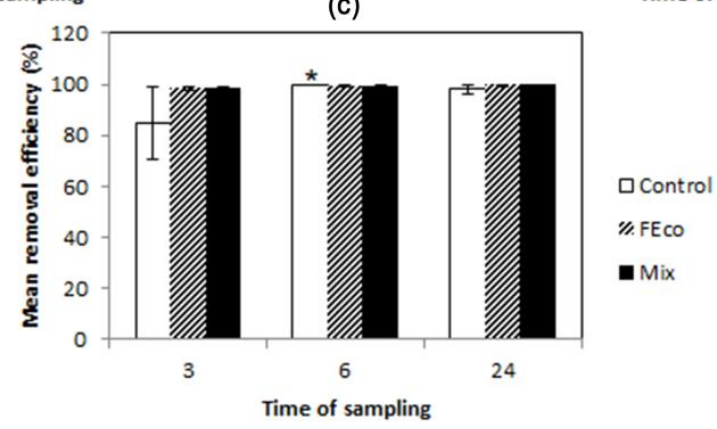

Figure 3: Mean removal of: a) DCF; b) IBU; c) NAP, in Control filter ( $n=9)$, FEco ( $n$ $=27)$ and Mix $(\mathrm{n}=27)$. The $*$ corresponds to the situations when, in one or more samples of the raw water, the compounds were not detected, thereby disabling the calculation of the standard deviation and consequently the error.

(1)

(1)

Assessing the types of filter MANOVA test shows that there were no differences between the filters (Control, FEco and Mix filters) for DCF, but indicates there was one effluent concentration significantly different to the others $(p=0.04)$ between collection times. However, the specific analysis of contrasts (Table S8) did not show the difference indicated by the general test. In this case it was considered the difference between the mean concentrations at the times 6 and 24 hours, since they were, respectively, the highest and the lowest sample means (3 hours: $0.04 \mu \mathrm{g} \mathrm{L}^{-1}, 6$ hours: $0.06 \mu \mathrm{g} \mathrm{L}^{-1}, 24$ hours: $\left.0.02 \mu \mathrm{g} \mathrm{L}^{-1}\right)$. For IBU, MANOVA shows no significant difference $(p>0.05)$ between the types of filters (Control, FEco and Mix filters), between the sampling times (3, 6 and 24 hours), and between the types of filter and 
sampling time (Figure 3b). For NAP, MANOVA shows that there were also no

447 differences between the types of filters (Control, FEco or Mix filters). However, the tests indicate there was at least one concentration different in relation to the others at times 3, 6 and 24 hours $(p=0.01)$. The specific analysis of contrasts identified that the difference was between 3 and 24 hours (Table S7). At the sampling time of 24 hours the effluent concentration of NAP was lower than in the two previous sampling times, with the values of the sample means as $0.02 \mu \mathrm{g} \mathrm{L} \mathrm{L}^{-1}$ in the time of 3 hours; $0.01 \mu \mathrm{g} \mathrm{L}^{-1}$ at 6 hours; and $0.001 \mu \mathrm{g} \mathrm{L}^{-1}$ at 24 hours after the contamination of the filters.

\subsubsection{Removal of personal care products}

The removal of personal care products by ecological filters was lower than the removal of pharmaceutical compounds; this may have been due to the fact MEP and BP-3 were found with high concentrations in the Lobo reservoir water as discussed above. However, MEP and BP-3 had similar removals of on average $70 \%$ and $71 \%$, respectively (Figure 4). On the other hand, Pompei et al. (2017) reported $100 \%$ removal of $2 \mu \mathrm{g} \mathrm{L}^{-1}$ of MEP and BP-3 by household SSF. However, these compounds were not found in the water of Regent's Park as identified in the Lobo reservoir water. Verlicchi et al. (2014) performed a literature review on the removal of personal care products by wetlands in Europe, North America and Asia, showing that removal was influenced mainly by redox potential, temperature, hydraulic retention time and affluent concentration of the compound. This may explain the difference between the findings by Pompei et al. (2017) and ours. Furthermore, when compared with other treatment processes the removal of MEP and BP-3 was not as high as those achieved by AOPs (Tayo et al., 2018). However, it should be noted that Gomes et al. (2017) reported the 
generation of toxic by-products of paraben which are not completely mineralized when photocatalytic ozonation using $\mathrm{TiO}_{2}$ was used.

Finally, despite the differences in removal of MEP in the Control filter in relation to the other filters (Figure 4b), MANOVA tests show that there were no difference between the treatments (Control, FEco or Mix filters) $(p>0.05)$, between sampling times of 3, 6 and 24 hours $(p=0.35)$, and between types of filter and sampling time $(p>0.05)$. For BP-3, the MANOVA tests show there were no difference between the treatments (Control, FEco or Mix filters) $(p>0.05)$, but there was a difference between sampling time $(p=0.02)$. The specific analysis of contrasts identified that the difference was between 3 hours $\left(0.99 \mu \mathrm{g} \mathrm{L}^{-1}\right)$ and 24 hours $\left(0.35 \mu \mathrm{g} \mathrm{L}^{-1}\right)$ (Table S7).
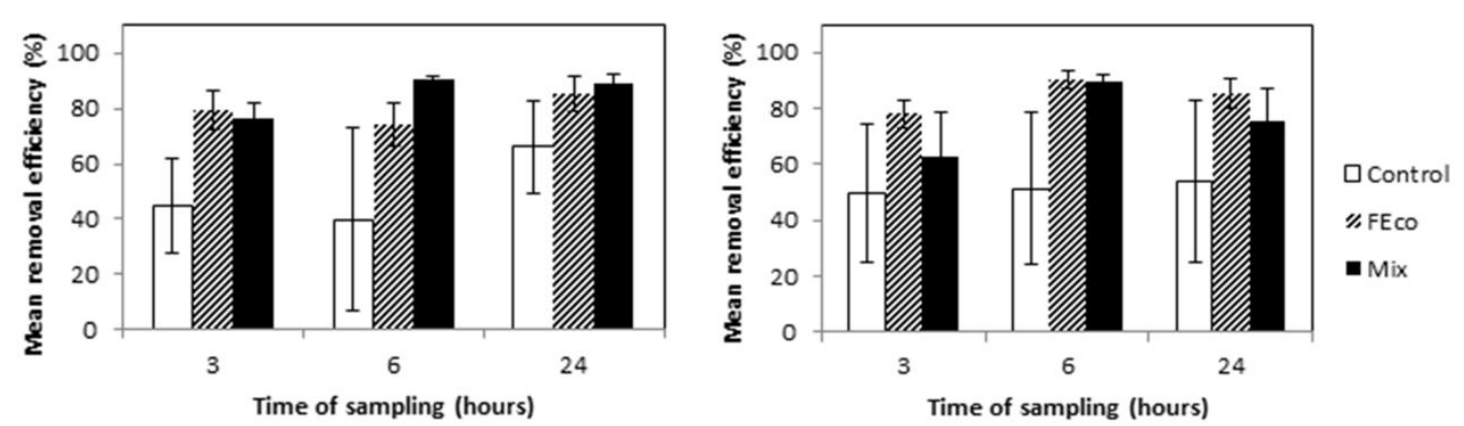

Figure 4: Mean removals of personal care products for a) BP-3 and b) MEP, in Control filter $(n=9)$, FEco $(n=27)$ and Mix $(n=27)$.

\section{Conclusions}

The results of water quality parameters indicated that the water treated by the ecological filters was within the standard of potability from Brazil. It is noted that filtered water needs to be disinfected for human consumption to totally remove coliforms.

The target PPCPs were identified in the Lobo reservoir water in the range of $\mu \mathrm{g}$ $\mathrm{L}^{-1}$. The personal care products were detected with $100 \%$ frequency in samples, and in 
high concentrations compared to the pharmaceutical compounds. These results were attributed to recreational use of the reservoir and wastewater effluent discharges.

Two DPs (DCF and BP-3) were identified in the reservoir and effluent filter water samples. The fragment ions were identified, and a degradation path for both compounds were proposed. To evaluate their removal by ecological filters a further investigation on quantification of the DP compounds is recommended.

Ecological filters removed more of the pharmaceutical compounds (81 to $99 \%$ ) than the personal care products ( 70 to $71 \%$ ). The statistical tests by MANOVA did not show significant differences for any of the compounds in relation to the type of filter (Control, FEco or Mix filters), showing the robustness of the ecological filtration system. Results showed that the filters are resilient to an individual compound as to their mixture. Some compounds (DCF, NAP, and BP-3) showed differences between some of the sampling times, but this was probably due to the variation of background contamination in the reservoir water and the spiked contamination of $2 \mu \mathrm{g} \mathrm{L} \mathrm{L}^{-1}$.

In comparison with other advanced technologies (e.g. ozone, fenton, UV irradiation) that may remove $100 \%$ of our target PPCPs, the authors believe that with optimised operational conditions, ecological filtration offers a low cost and chemical free treatment option for the effective PPCP removal in decentralized systems.

\section{Acknowledgements}

This research was financially supported by the São Paulo Research Foundation, Brazil (FAPESP) n. 2012/21981-7, and Dr Caroline Moço Erba Pompei was supported by FAPESP through the scholarship n. 2011/21666-1. Authors thanks also the project $n$. 2008/10449-7 (FAPESP) for the LC-MS/MS. 


\section{References}

Agüera, A., Pérez Estrada, L. A., Ferrer, I., Thurman, E. M., Malato, S., \& Fernández-Alba, A. R., 2005. Application of time-of-flight mass spectrometry to the analysis of phototransformation products of diclofenac in water under natural sunlight. Journal of Mass Spectrometry, 40(7), 908-915. doi: 10.1002/jms.867

Almeida, G. A. D., Weber, R. R., 2009. Fármacos na represa Billings. Revista Saúde e Ambiente, 6(2), 7-13.

Andrés-Costa, M. J., Rubio-López, N., Suárez-Varela, M. M., \& Pico, Y., 2014. Occurrence and removal of drugs of abuse in Wastewater Treatment Plants of Valencia (Spain). Environmental pollution, 194, 152-162. doi: 10.1016/j.envpol.2014.07.019

Bellamy, W.D.; Hendricks. D.W. and Longsdon, G.S., 1985. "Slow and Filtration” Journal of the American Water Works Association. 77(12), p.62-66.

Benijts, T., Lambert, W., \& De Leenheer, A., 2004. Analysis of multiple endocrine disruptors in environmental waters via wide-spectrum solid-phase extraction and dual-polarity ionization LC-ion trap-MS/MS. Analytical chemistry, 76(3), 704-711. doi:10.1021/ac035062x

Beretelkamp, C. Reungoat, J., Cornelissen, E.R., Singhal, N., Reynisson, J., Cabo, A.J., Van Der Hoek, J.P., Verliefd, A.R.D., 2014. Sorption and biodegradation of organic micropollutants during river bank filtration: a laboratory column study. Water research, 52, 231-241. doi: 10.1016/j.watres.2013.10.068

Blanco, E., del Carmen Casais, M., del Carmen Mejuto, M., \& Cela, R., 2009. Combination of off-line solid-phase extraction and on-column sample stacking for sensitive determination of parabens and p-hydroxybenzoic acid in waters by non-aqueous capillary electrophoresis. Analytica chimica acta, 647(1), 104-111. doi:10.1016/j.aca.2009.05.024

Bound, J. P., \& Voulvoulis, N., 2006. Predicted and measured concentrations for selected pharmaceuticals in UK rivers: implications for risk assessment. Water Research, 40(15), 2885-2892. doi:10.1016/j.watres.2006.05.036

Brasil, 2011. Ministério da Saúde. Portaria nº 2.914, de 12 de dezembro de 2011. Dispõe sobre os procedimentos de controle e de vigilância da qualidade da água para consumo humano e 
seu padrão de potabilidade. Diário Oficial da União [da] República Federativa do Brasil. Seção 1, p. 26.

549 Calijuri, M. C., \& Tundisi, J. G., 1990. Limnologia comparada das represas do Lobo (Broa) e 550 Barra Bonita-Estado de São Paulo: mecanismos de funcionamento e bases para o gerenciamento. Revista Brasileira de Biologia, 50(4), 893-913.

552 Camacho-Munoz, D., Martín, J., Santos, J. L., Alonso, E., Aparicio, I., De la Torre, T., \& Malfeito, J. J., 2012. Effectiveness of three configurations of membrane bioreactors on the removal of priority and emergent organic compounds from wastewater: comparison with conventional wastewater treatments. Journal of Environmental Monitoring, 14(5), 14281436. doi:10.1039/C2EM00007E

Campos, L.C., M.F.J. Su, Graham N.J.D \& Smith, S.R. 2002 Biomass development in slow sand filters. Water Research, International: 36(18), 4543-4551. doi: 10.1016/S00431354(02)00167-7.

Chen, D. Y., Guo, X. F., Wang, H., \& Zhang, H. S., 2015. The natural degradation of benzophenone at low concentration in aquatic environments. Water Science and Technology, 72(4), 503-509. doi:10.2166/wst.2015.221

Chen, Y., Vymazal, J., Březinová, T., Koželuh, M., Kule, L., Huang, J., \& Chen, Z., 2016. Occurrence, removal and environmental risk assessment of pharmaceuticals and personal care products in rural wastewater treatment wetlands. Science of the Total Environment, 566, 1660-1669. doi:10.1016/j.scitotenv.2016.06.069

Daughton, C. G., \& Ternes, T. A., 1999. Pharmaceuticals and personal care products in the

570 Delpla, I., Jung, A. V., Baures, E., Clement, M., \& Thomas, O., 2009. Impacts of climate change on surface water quality in relation to drinking water production. Environment international, 35(8), 1225-1233. doi:10.1016/j.envint.2009.07.001 
Dévier, M. H., Mazellier, P., Ait-Aissa, S., \& Budzinski, H., 2011. New challenges in environmental analytical chemistry: identification of toxic compounds in complex mixtures. Comptes Rendus Chimie, 14(7-8), 766-779. doi:10.1016/j.crci.2011.04.006

Di Bernardo, L., 1993. Métodos e técnicas de tratamento de água. In Métodos e técnicas de tratamento de água. Abes.

Di Bernardo, L., \& Rivera, E. 1996. Influence of sand uniformity coefficient on slow sand filtration performance. Advances in Slow Sand and Biological Filtration, 179-188.

Ellis, J. B., 2006. Pharmaceutical and personal care products (PPCPs) in urban receiving waters. Environmental pollution, 144(1), 184-189. doi:10.1016/j.envpol.2005.12.018

Erba, C. M., Tangerino, E. P., Carvalho, S. L. D., \& Isique, W. D., 2012. Remoção de diclofenaco, ibuprofeno, naproxeno e paracetamol em filtro ecológico seguido por filtro de carvão granular biologicamente ativado. Engenharia Sanitária e Ambiental, 137-142. doi:10.1590/S1413-41522012000200002.

Erba, C. M.; Tangerino, E.P.; Isique, W. D.; Campos, L. C. , 2014. Removal of antiinflammatory compounds by ecological filtration. In: Nobutada Nakamoto, Nigel Graham, M. Robin Collins and Rolf Gimbel. (2014) (Org.). Progress in slow sand and alternative biofiltration process. 1ed.: IWA publishing. v. 5, cap 19, p. 147-152.

Escolà Casas, M., Bester, K., 2015. Can those organic micro-pollutants that are recalcitrant in activated sludge treatment be removed from wastewater by biofilm reactors (slow sand filters)?. Science of the Total Environment, 506, 315-322. doi:10.1016/j.scitotenv.2014.10.113

Evgenidou, E. N., Konstantinou, I. K., \& Lambropoulou, D. A., 2015. Occurrence and removal of transformation products of PPCPs and illicit drugs in wastewaters: a review. Science of the Total Environment, 505, 905-926. doi:10.1016/j.scitotenv.2014.10.021

Fent, K., Weston, A. A., \& Caminada, D., 2006. Ecotoxicology of human pharmaceuticals. Aquatic toxicology, 76(2), 122-159. doi:10.1016/j.aquatox.2005.09.009

François, B., Armand, M., Marie-José, D., \& Thouand, G. 2016. From laboratory to environmental conditions: a new approach for chemical's biodegradability assessment. 

016-7062-х

Fujii, K., \& Kikuchi, S., 2005. Degradation of benzophenone, a potential xenoestrogen, by a yeast isolated from the activated sludge of a sewage treatment plant in Hokkaido. World Journal of Microbiology and Biotechnology, 21(6-7), 1311-1315. doi:10.1007/s11274-005-

$$
\text { 2704-z }
$$

Galinaro, C. A., Pereira, F. M., \& Vieira, E. M., 2015. Determination of parabens in surface water from Mogi Guaçu River (São Paulo, Brazil) using dispersive liquid-liquid microextraction based on low density solvent and LC-DAD. Journal of the Brazilian Chemical Society, 26(11), 2205-2213. doi:10.5935/0103-5053.20150206

Goel, M., \& Das, A. 2018. A Review on Treatment of Pharmaceuticals and Personal Care Products (PPCPs) in Water and Wastewater. Handbook of Environmental Materials Management, 1-12. doi:10.1007\%2F978-3-319-58538-3_41-1

Gomes, J., Costa, R., Quinta-Ferreira, R. M., \& Martins, R. C. 2017. Application of ozonation for pharmaceuticals and personal care products removal from water. Science of The Total Environment, 586, 265-283. doi: 10.1016/j.scitotenv.2017.01.216

Gong, H., Klinger, J., Damazyn, K., Li, X., \& Huang, S., 2015. A novel procedure for statistical inference and verification of gene regulatory subnetwork. BMC bioinformatics, 16(7), S7. doi:10.1186/1471-2105-16-S7-S7

Gros, M., Petrović, M., \& Barceló, D., 2006. Development of a multi-residue analytical methodology based on liquid chromatography-tandem mass spectrometry (LC-MS/MS) for screening and trace level determination of pharmaceuticals in surface and wastewaters. Talanta, 70(4), 678-690. doi:10.1016/j.talanta.2006.05.024

Hallé, C., 2010. Biofiltration in drinking water treatment: Reduction of membrane fouling and biodegradation of organic trace contaminants. http://hdl.handle.net/10012/5022

Haman, C., Dauchy, X., Rosin, C., \& Munoz, J. F., 2015. Occurrence, fate and behavior of parabens in aquatic environments: a review. Water research, 68, 1-11. doi:10.1016/j.watres.2014.09.030 
Heberer, T., 2002. Occurrence, fate, and removal of pharmaceutical residues in the aquatic environment: a review of recent research data. Toxicology letters, 131(1-2), 5-17. doi:10.1016/S0378-4274(02)00041-3

Henschel, K. P., Wenzel, A., Diedrich, M., \& Fliedner, A., 1997. Environmental hazard assessment of pharmaceuticals. Regulatory Toxicology and Pharmacology, 25(3), 220-225. doi:10.1006/rtph.1997.1102

Isensee, A. R., 1976. Variability of aquatic model ecosystem-derived data. International Journal of Environmental Studies, 10(1), 35-41.

Jones, O. A., Lester, J. N., \& Voulvoulis, N., 2005. Pharmaceuticals: a threat to drinking water? TRENDS in Biotechnology, 23(4), 163-167. doi:10.1016/j.tibtech.2005.02.001

Jonkers, N., Sousa, A., Galante-Oliveira, S., Barroso, C. M., Kohler, H. P. E., \& Giger, W., 2010. Occurrence and sources of selected phenolic endocrine disruptors in Ria de Aveiro, Portugal. Environmental Science and Pollution Research, 17(4), 834-843. doi:10.1007/s11356-009-0275-5

Kim, S., \& Choi, K., 2014. Occurrences, toxicities, and ecological risks of benzophenone-3, a common component of organic sunscreen products: a mini-review. Environment international, 70, 143-157. doi:10.1016/j.envint.2014.05.015

Li, J., Zhou, Q., \& Campos, L. C., 2018. The application of GAC sandwich slow sand filtration to remove pharmaceutical and personal care products. Science of the Total Environment, 635, 1182-1190. doi:10.1016/j.scitotenv.2018.04.198

Lin, A. Y. C., Lin, C. A., Tung, H. H., \& Chary, N. S., 2010. Potential for biodegradation and sorption of acetaminophen, caffeine, propranolol and acebutolol in lab-scale aqueous environments. Journal of Hazardous Materials, 183(1-3), 242-250. doi:10.1016/j.jhazmat.2010.07.017

Löffler, D., \& Ternes, T. A., 2003. Determination of acidic pharmaceuticals, antibiotics and ivermectin in river sediment using liquid chromatography-tandem mass spectrometry. Journal of Chromatography A, 1021(1-2), 133-144. doi:10.1016/j.chroma.2003.08.089 
Loraine, G. A., \& Pettigrove, M. E., 2006. Seasonal variations in concentrations of pharmaceuticals and personal care products in drinking water and reclaimed wastewater in southern California. Environmental Science \& Technology, 40(3), 687-695. doi:10.1021/es051380x

Magi, E., Scapolla, C., Di Carro, M., Rivaro, P., \& Nguyen, K. T. N., 2013. Emerging pollutants in aquatic environments: monitoring of UV filters in urban wastewater treatment plants. Analytical Methods, 5(2), 428-433. doi:10.1039/C2AY26163D

Matamoros, V., Arias, C., Brix, H., \& Bayona, J. M., 2009. Preliminary screening of small-scale domestic wastewater treatment systems for removal of pharmaceutical and personal care products. Water Research, 43(1), 55-62. doi:10.1016/j.watres.2008.10.005

Miao, X. S., Koenig, B. G., \& Metcalfe, C. D., 2002. Analysis of acidic drugs in the effluents of sewage treatment plants using liquid chromatography-electrospray ionization tandem mass spectrometry. Journal of chromatography A, 952(1-2), 139-147. doi: 10.1016/S00219673(02)00088-2

Mompelat, S., Le Bot, B., \& Thomas, O., 2009. Occurrence and fate of pharmaceutical products and by-products, from resource to drinking water. Environment international, 35(5), 803 814. doi: 10.1016/j.envint.2008.10.008

Montagner, C. C., \& Jardim, W. F., 2011. Spatial and seasonal variations of pharmaceuticals and endocrine disruptors in the Atibaia River, São Paulo State (Brazil). Journal of the Brazilian Chemical Society, 22(8), 1452-1462. doi: 10.1590/S0103-50532011000800008

Nakamoto, N., 2008. Produza você mesmo uma água saborosa - sistema de purificação ecológica - revendo a tecnologia de produção de água potável. São Paulo: Ferrari. 210 p.

Oliveira, L. L.D., 2014. Biomarcadores enzimáticos e testes ecotoxicológicos na avaliação da toxicidade de fármacos em invertebrados aquáticos. Tese (Doutorado em Ciências da Engenharia Ambiental) - Universidade de São Paulo, Escola de Engenharia de São Carlos.

Onesios, K. M., Jim, T. Y., \& Bouwer, E. J., 2009. Biodegradation and removal of pharmaceuticals and personal care products in treatment systems: a review. Biodegradation, 20(4), 441-466. doi: 10.1007/s10532-008-9237-8 
Parolini, M., Binelli, A., Cogni, D., Riva, C., \& Provini, A., 2009. An in vitro biomarker approach for the evaluation of the ecotoxicity of non-steroidal anti-inflammatory drugs (NSAIDs). Toxicology in vitro, 23(5), 935-942. doi: 10.1016/j.tiv.2009.04.014

Pedrouzo, M., Borrull, F., Marcé, R. M., \& Pocurull, E., 2009. Ultra-high-performance liquid chromatography-tandem mass spectrometry for determining the presence of eleven personal care products in surface and wastewaters. Journal of Chromatography A, 1216(42), 69947000. doi: 10.1016/j.chroma.2009.08.039

Peng, X., Yu, Y., Tang, C., Tan, J., Huang, Q., \& Wang, Z., 2008. Occurrence of steroid estrogens, endocrine-disrupting phenols, and acid pharmaceutical residues in urban riverine water of the Pearl River Delta, South China. Science of the total environment, 397(1-3), 158166. doi: $10.1016 /$ j.scitotenv.2008.02.059

Petrović, M., Gonzalez, S., \& Barceló, D., 2003. Analysis and removal of emerging contaminants in wastewater and drinking water. TrAC Trends in Analytical Chemistry, 22(10), 685-696. doi: 10.1016/S0165-9936(03)01105-1

Poiger, T., Buser, H. R., Balmer, M. E., Bergqvist, P. A., \& Müller, M. D., 2004. Occurrence of UV filter compounds from sunscreens in surface waters: regional mass balance in two Swiss lakes. Chemosphere, 55(7), 951-963. doi: 10.1016/j.chemosphere.2004.01.012

Pojana, G., Fantinati, A., \& Marcomini, A., 2011. Occurrence of environmentally relevant pharmaceuticals in Italian drinking water treatment plants. International journal of environmental analytical chemistry, 91(6), 537-552. doi: 10.1080/03067310903531504

Pompei, C. M., Ciric, L., Canales, M., Karu, K., Vieira, E. M., \& Campos, L. C., 2017. Influence of PPCPs on the performance of intermittently operated slow sand filters for household water purification. Science of the Total Environment, 581, 174-185. doi: 10.1016/j.scitotenv.2016.12.091

Postigo, C., \& Richardson, S. D., 2014. Transformation of pharmaceuticals during oxidation/disinfection processes in drinking water treatment. Journal of hazardous materials, 279, 461-475. doi: 10.1016/j.jhazmat.2014.07.029 
Qiao, T., Yu, Z., Zhang, X., \& Au, D. W., 2011. Occurrence and fate of pharmaceuticals and personal care products in drinking water in southern China. Journal of Environmental Monitoring, 13(11), 3097-3103. doi: 10.1039/C1EM10318K

Ramaswamy, B. R., Shanmugam, G., Velu, G., Rengarajan, B., \& Larsson, D. J., 2011. GC-MS analysis and ecotoxicological risk assessment of triclosan, carbamazepine and parabens in Indian rivers. Journal of hazardous materials, 186(2-3), 1586-1593. doi: 10.1016/j.jhazmat.2010.12.037

Ranjard, L., Dequiedt, S., Prévost-Bouré, N. C., Thioulouse, J., Saby, N. P. A., Lelievre, M., P. A. Maron, F.E.R Morin, A. Bispo, C. Jolivet, D. Arrouays \& P. Lemanceau 2013. Turnover of soil bacterial diversity driven by wide-scale environmental heterogeneity. Nature communications, 4, 1434. doi:10.1038/ncomms2431

Renz, L., Volz, C., Michanowicz, D., Ferrar, K., Christian, C., Lenzner, D., \& El-Hefnawy, T., 2013. A study of parabens and bisphenol A in surface water and fish brain tissue from the Greater Pittsburgh Area. Ecotoxicology, 22(4), 632-641. doi:10.1007/s10646-013-1054-0

Rigobello, E. S., Dantas, A. D. B., Di Bernardo, L., \& Vieira, E. M., 2013. Removal of diclofenac by conventional drinking water treatment processes and granular activated carbon filtration. Chemosphere, 92(2), 184-191. doi: 10.1016/j.chemosphere.2013.03.010

Rodil, R., \& Moeder, M., 2008. Development of a method for the determination of UV filters in water samples using stir bar sorptive extraction and thermal desorption-gas chromatography-mass spectrometry. Journal of Chromatography A, 1179(2), 81-88. doi: 10.1016/j.chroma.2007.11.090

Schumock, G.T., Li, E.C., Suda, K.J., Matusiak, L.M., Hunkler, R.J., Vermeulen, L.C., Hoffman, J.M., 2014. National trends in prescription drug expenditures and projections for 2014. American Journal of Health-System Pharmacy]->Am. J. Health Syst. Pharm. 71 (6), 482-499. doi: 10.2146/ajhp130767

Silva, C. P. D., Emídio, E. S., \& de Marchi, M. R., 2013. UV filters in water samples: experimental design on the SPE optimization followed by GC-MS/MS analysis. Journal of the Brazilian Chemical Society, 24(9), 1433-1441. doi: 10.5935/0103-5053.20130182 
Sotelo, J. L., Ovejero, G., Rodríguez, A., Álvarez, S., Galán, J., \& García, J., 2014. Competitive adsorption studies of caffeine and diclofenac aqueous solutions by activated carbon. Chemical engineering journal, 240, 443-453. doi:10.1016/j.cej.2013.11.094

Stumpf, M., Ternes, T. A., Wilken, R. D., Rodrigues, S. V., \& Baumann, W., 1999. Polar drug residues in sewage and natural waters in the state of Rio de Janeiro, Brazil. Science of the total environment, 225(1-2), 135-141. doi: 10.1016/S0048-9697(98)00339-8

Sui, Q., Cao, X., Lu, S., Zhao, W., Qiu, Z., \& Yu, G., 2015. Occurrence, sources and fate of pharmaceuticals and personal care products in the groundwater: a review. Emerging Contaminants, 1(1), 14-24. doi: 10.1016/j.emcon.2015.07.001

Tayo, L. L., Caparanga, A. R., Doma, B. T., \& Liao, C. H. (2018). A review on the removal of pharmaceutical and personal care products (PPCPs) using advanced oxidation processes. Journal of Advanced Oxidation Technologies, 21(1), 196-214. doi:10.26802/jaots.2017.0079

Ternes, T.A., 1998. Occurrence of drugs in German sewage treatment plants and rivers. Water Research. 32, 3245-3260.doi: 10.1016/S0043-1354(98)00099-2

Ternes, T.; Hirsch, R.; Mueller, J.; Haberer, K., 1998. Methods for the determination of neutral drugs as well as betablockers and alpha2-sympathomimetics in aqueous matrices using GC/MS and LC/MS/MS. Fresen Journalof Analytical Chemistry. v. 362, p. 329-40. doi: $10.1007 / \mathrm{s} 002160051083$

Thomas, P. M., \& Foster, G. D., 2004. Determination of Nonsteroidal Anti-inflammatory Drugs, Caffeine, and Triclosan in Wastewaterby Gas Chromatography-Mass Spectrometry. Journal of Environmental Science and Health, Part A, 39(8), 1969-1978. doi: 10.1081/ESE120039368

Van Doorslaer, X., Dewulf, J., Van Langenhove, H., \& Demeestere, K., 2014. Fluoroquinolone antibiotics: an emerging class of environmental micropollutants. Science of the Total Environment, 500, 250-269. doi: 10.1016/j.scitotenv.2014.08.075

Verlicchi, P., Zambello, E., \& Al Aukidy, M. 2014. Removal of personal care products in constructed wetlands. In: Personal Care Products in the Aquatic Environment. Springer, Cham, 319-353. doi: 10.1007/698_2014_282 
767 Vieno, N. M., Härkki, H., Tuhkanen, T., \& Kronberg, L., 2007. Occurrence of pharmaceuticals

768 in river water and their elimination in a pilot-scale drinking water treatment

769 plant. Environmental science \& technology, 41(14), 5077-5084. doi:10.1021/es062720x

770 Westerhoff, P., 2003. Removal of endocrine disruptors, pharmaceuticals, and personal care

771 products during water treatment. Southwest hydrology, 2(6), 18-19.

772 Wiesenberg-Boettcher, I., Pfeilschifter, J., Schweizer, A., Sallmann, A., \& Wenk, P., 1991.

773 Pharmacological properties of five diclofenac metabolites identified in human plasma.

774 Agents and actions, 34(1-2), 135-137. doi:10.1007/BF01993259

775 Winkler, M., Lawrence, J. R., \& Neu, T. R., 2001. Selective degradation of ibuprofen and

776 clofibric acid in two model river biofilm systems. Water Research, 35(13), 3197-3205.

777 doi:10.1016/S0043-1354(01)00026-4

778 Xu, Y., Liu, T., Zhang, Y., Ge, F., Steel, R. M., \& Sun, L. 2017. Advances in technologies for 779 pharmaceuticals and personal care products removal. Journal of Materials Chemistry A, 5(24), 12001-12014. doi:10.1039/C7TA03698A 


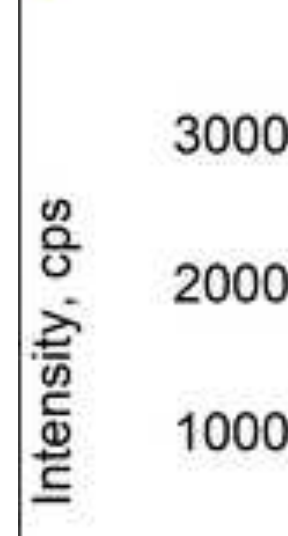

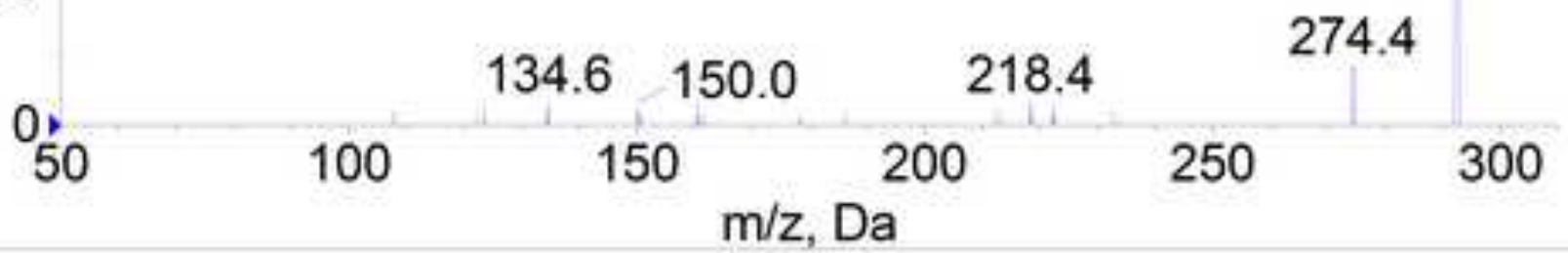<smiles></smiles>

$m / z 292$<smiles>O=CCC1=CC(=O)C=CC1=Nc1c(O)cccc1Cl</smiles>

$m / 2274$

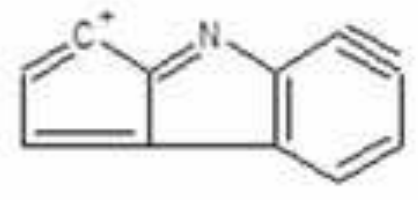

$m / z 150$

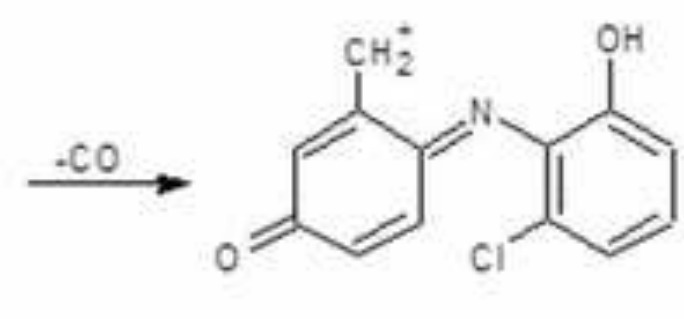

$m / z 246$<smiles>CC(C)=O</smiles>
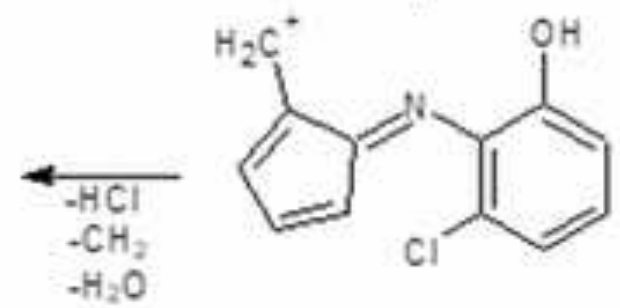

$m / z 218$ 

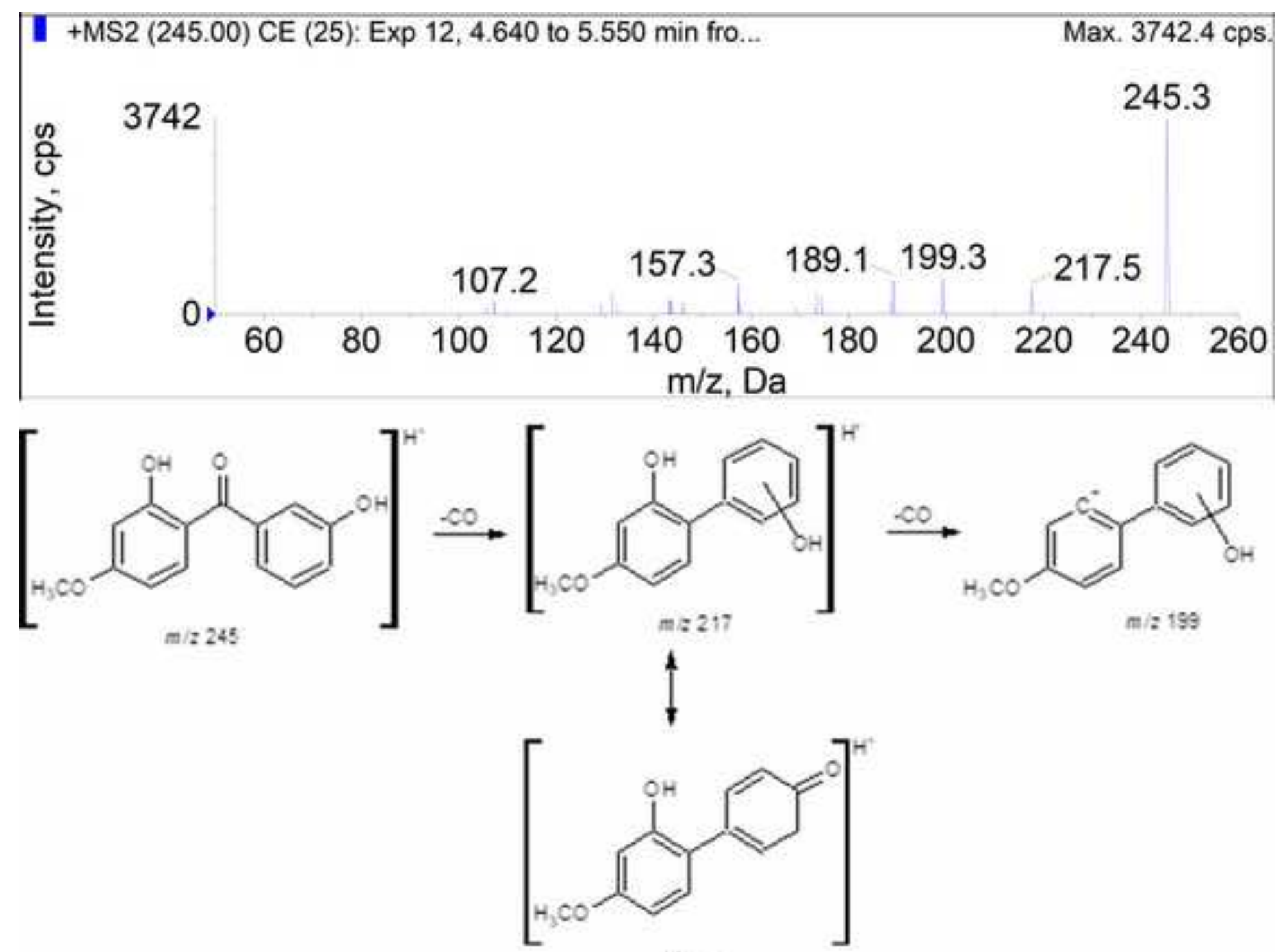

$1+\infty$

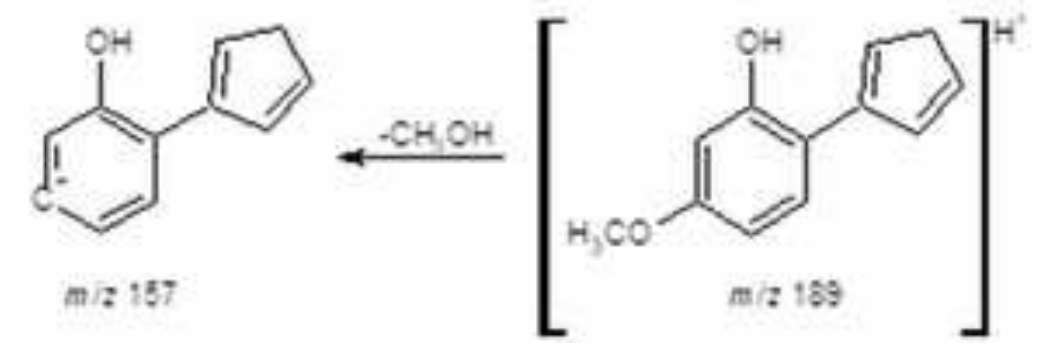




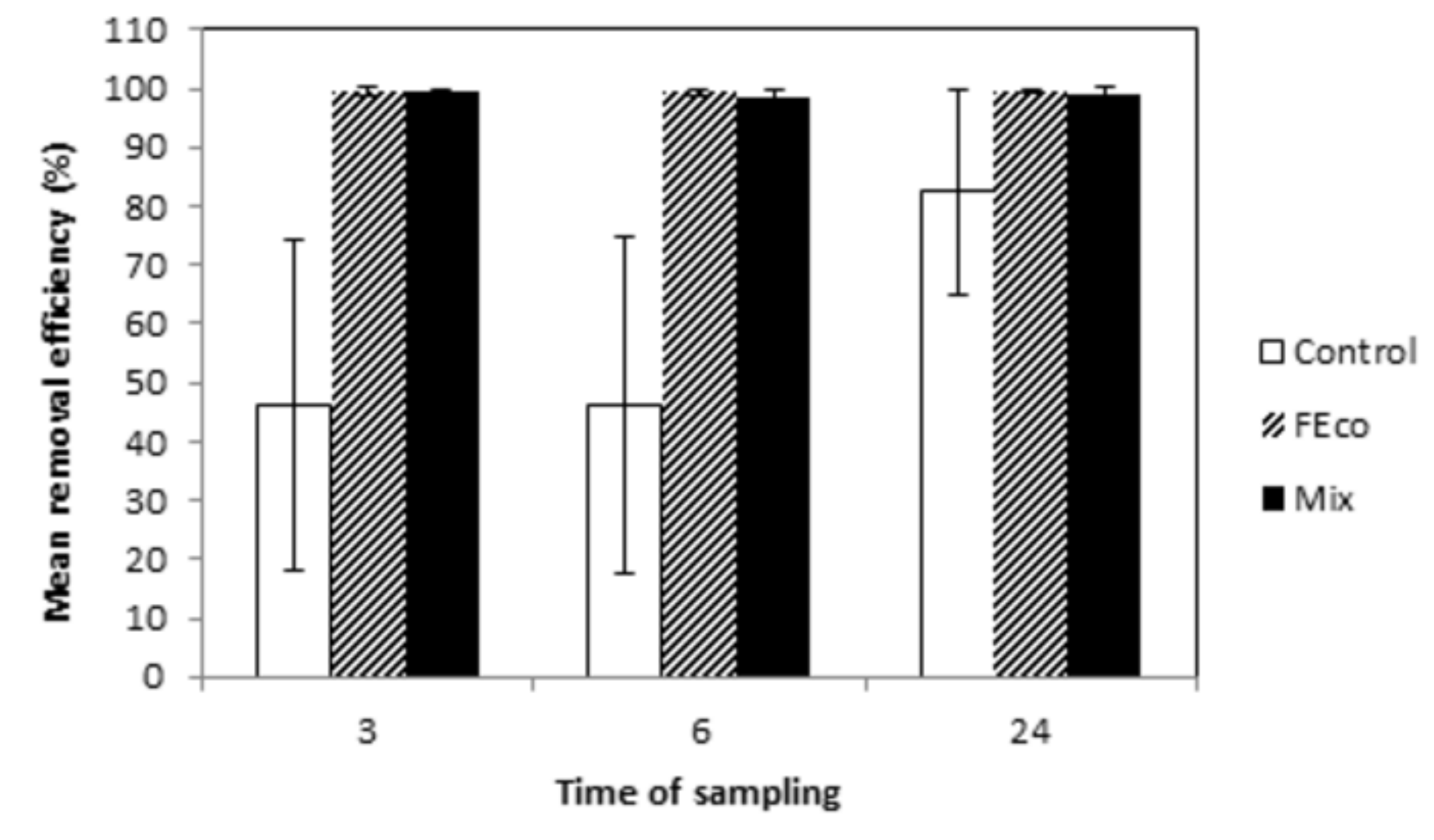


(a)

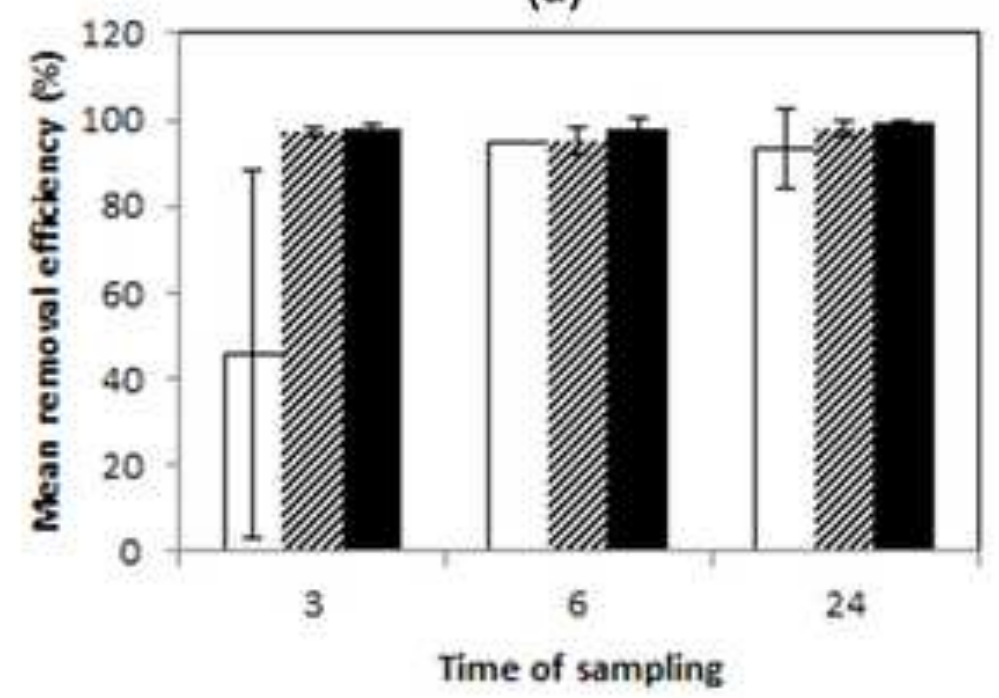

Time of sampling
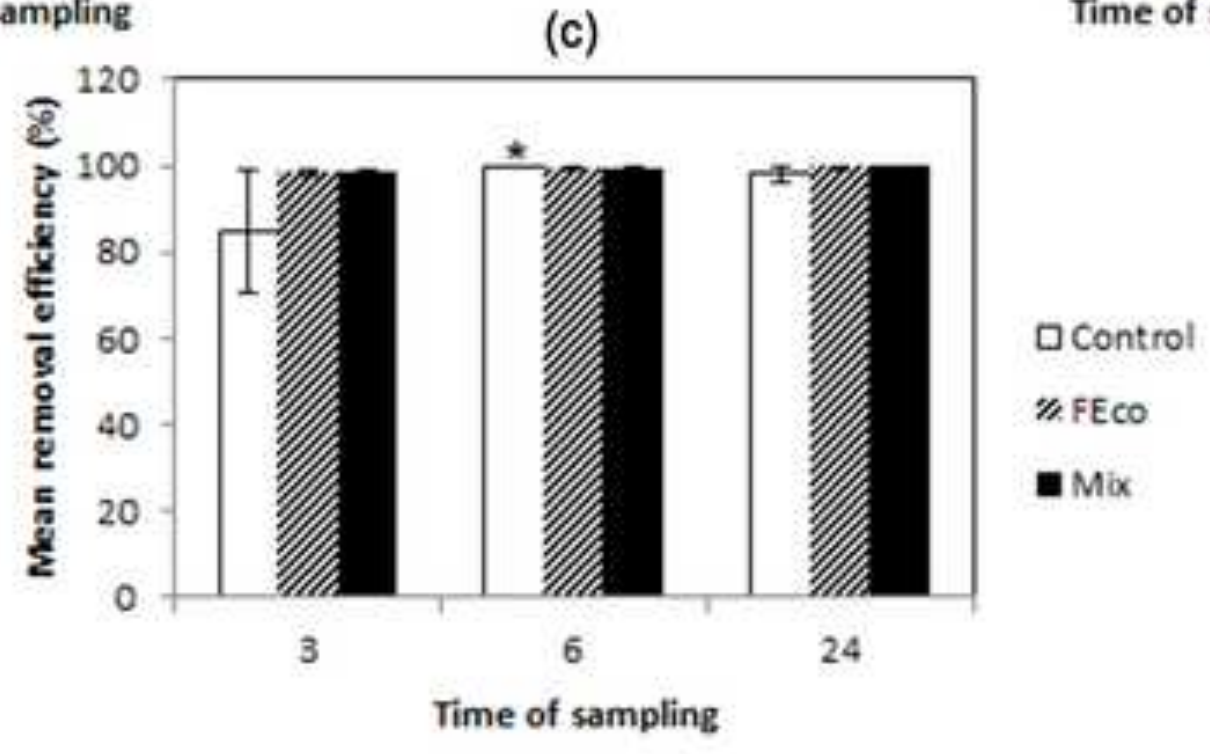

(c)

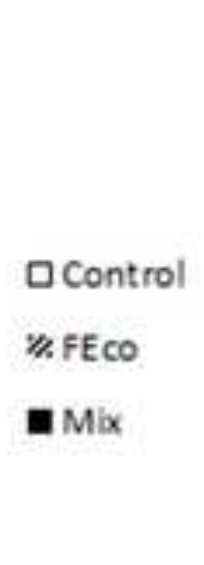

(b)

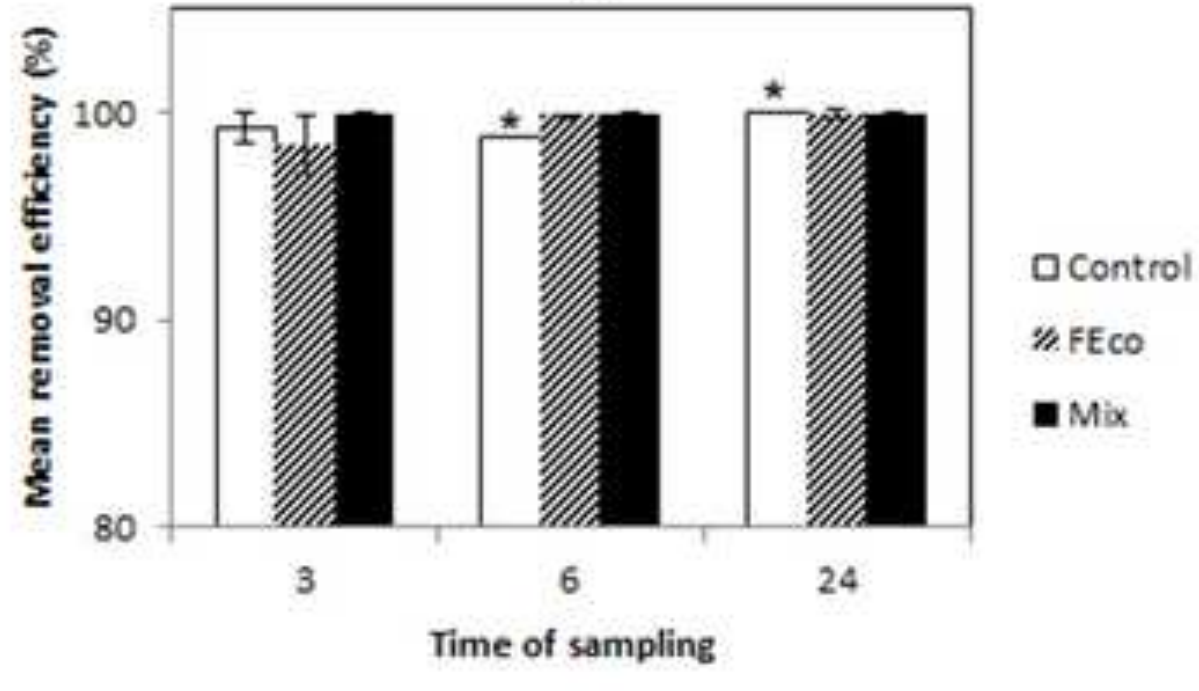

Control 

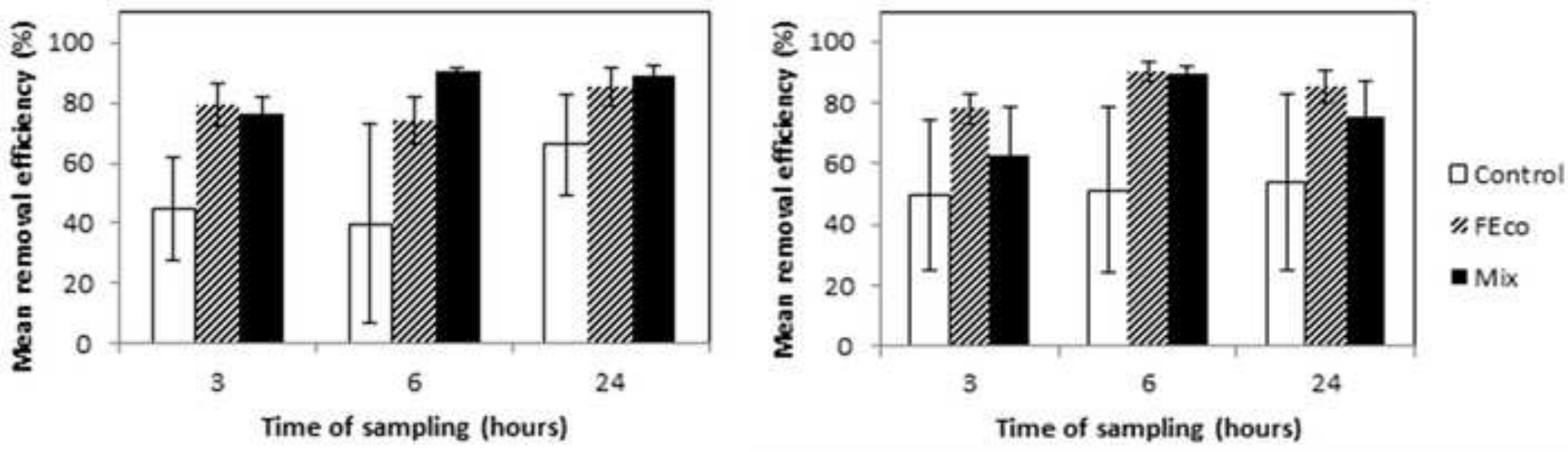


\section{Table and Figure Captions}

Table 1: Concentrations of the compounds detected by SPE-LC-MS/MS in water samples from the Lobo reservoir.

Figure 1: Identified fragment ions spectra of the degradation products (DPs), and proposed fragmentation mechanism for both water reservoir and effluent of the ecological filters: a) DP of DCF; b) DP of BP-3.

Figure 2: Mean removal $(\%)$ of ACT by ecological filtration, in Control filter $(n=9)$, FEco $(\mathrm{n}=27)$ and Mix $(\mathrm{n}=27)$.

Figure 3: Mean removal of: a) DCF; b) IBU; c) NAP, in Control filter ( $n=9)$, FEco ( $n$ $=27)$ and Mix $(n=27)$. The * corresponds to the situations when, in one or more samples of the raw water, the compounds were not detected, disabling the calculation of the standard deviation and consequently the error.

Figure 4: Mean removals of personal care products for a) BP-3 and b) MEP, in Control filter $(n=9)$, FEco $(n=27)$ and Mix $(n=27)$. 
Table 1: Concentrations of the compounds detected by SPE-LC-MS/MS in water samples from the Lobo reservoir.

\begin{tabular}{l|c|c|c|c}
\multicolumn{5}{c}{ Raw water } \\
\hline PPCPs & $\begin{array}{c}\text { Min. Conc. } \\
\left(\mu \mathrm{g} \mathrm{L}^{-1}\right)\end{array}$ & $\begin{array}{c}\text { Max. Conc. } \\
\left(\mu \mathrm{g} \mathrm{L}^{-1}\right)\end{array}$ & $\begin{array}{c}\text { Mean Conc. } \\
\left(\mu \mathrm{g} \mathrm{L}^{-1}\right)\end{array}$ & $\begin{array}{c}\text { Frequency } \\
\text { detected }(\%)\end{array}$ \\
\hline ACT & n.d. & 0.13 & 0.03 & 85.70 \\
DCF & n.d. & 0.05 & 0.02 & 71.40 \\
NAP & n.d. & 0.10 & 0.01 & 85.70 \\
IBU & n.d. & 0.13 & 0.01 & 42.80 \\
MEP & 0.10 & 1192.39 & 170.87 & 100.00 \\
BP-3 & 0.32 & 2.10 & 1.14 & 100.00 \\
\hline
\end{tabular}

n.d.: not detected; <LOQ: less than the limit of quantitation. 

Supplementary Material with no marked changes
Click here to download Supplementary Material: Supporting information with no marked_CHEM58245R2.docx 